\title{
Effect of Pre- and Post-harvest Treatments on Quality and Storability of "Manfalouty" Pomegranates under Room Temperature
}

\author{
Mostafa, F.M.A. ${ }^{1}$; A.A.B. Masoud ${ }^{1}$; R.A. Ibrahim ${ }^{1}$; Fatma E. Ibraheem ${ }^{2}$ \\ and Nagwa M. Omar ${ }^{2}$ \\ ${ }^{1}$ Pomology Dept., Faculty of Agricultural, Assiut University, Assiut, Egypt. \\ ${ }^{2}$ Agricultural Research Center, Cairo, Egypt.
}

Received on: 8/10/2018

Accepted for publication on: 9/10/2018

\section{Abstract}

This study was carried out during 2011 and 2012 seasons on "Manfalouty" pomegranate cv. grown at the experimental orchard of Pomology Department, Faculty of Agriculture, Assiut University. The objectives of this study were examining the effects of pre-harvest spray with $\mathrm{CaCl}_{2}(4 \%)$ and $\mathrm{GA}_{3}(100 \mathrm{ppm})$ as well as post-harvest treatments with jasmine oil $\left(2.5 \mathrm{~cm}^{3} / \mathrm{L}\right)$, olive oil $(2.5$ $\left.\mathrm{cm}^{3} / \mathrm{L}\right)$, fiber gard $\left(20 \mathrm{~cm}^{3} / \mathrm{L}\right)$ and wrapping individually fruit with food polyolefin stretch as an improving effect in physicochemical characteristics of "Manfalouty" pomegranate $\mathrm{cv}$. during storage under room temperature $\left(22 \pm 5^{\circ} \mathrm{C}\right)$. The experiments were set up on split-plot arrangements in complete randomized block design (CRBD), with three replicates, 20 fruits each. According to the obtained results of this study, it could be deduced that pre-harvest spray with $\mathrm{GA}_{3}$ $(100 \mathrm{ppm})$ gave in general, the best results on improving physical and chemical characteristics, followed by $\mathrm{CaCl}_{2}$ (4\%) during the two growth seasons, as well as wrapping individually fruits with food polyolefin stretch gave the best quality during shelf-life period, followed by dipping fruits in both jasmine oil or olive oil and fiber gard during fruit storage under room temperature. Therefore, the authors recommended with wrapping individually fruits to keep fruits with good quality during fruit storage under room temperature.

Keywords: $\mathrm{GA}_{3}, \mathrm{CaCl}_{2}$, Manfalouty pomegranate, natural oils and food polyolefin stretch

\section{Introduction}

Pomegranate cultivars (Punica granatum L.) are grown in many different regions, mainly in subtropical Mediterranean region. "Manfalouty" pomegranate $\mathrm{cv}$. is considered one of the most important pomegranate cvs. grown successfully in Egypt, mainly in Assiut Government. In recent years, production and consumption of pomegranate fruits are increasing rapidly due to the health benefits produced by the very high content of bioactive phytochemicals of the fruits (Opara et al., 2009 and Vinda-Martos et al., 2010).
Pomegranate fruits contain a substantial amount of polyphenols of high biological value including flavonoids (anthocyanins, flavonols), hydrolysable tannins (ellagitannins, gallotannins) condensed tannins (proathocyanidins), Fawole and Opara, 2013a, b. Despite these health benefits, pomegranate consumption is still limited due to the difficulty of extracting the arils (pomegranate grains).

These polyphenols exhibit various biological activities such as eliminating free radicals, inhibiting oxidation and microbial growth and 
decreasing the risk of cardio- and cerebra vascular diseases and some type of cancers (Mena et al., 2011).

Furthermore, the incidence of post-harvest losses and poor keeping quality of pomegranate fruits are largely attributed to the high sensitivity of their fruits to temperature below $4^{\circ} \mathrm{C}$ and above $10^{\circ} \mathrm{C}$ (Nanda et al., 2001). The storage temperature recommended for pomegranates varies from 5 to $7.5^{\circ} \mathrm{C}$ with shelf-life from 8 to 16 weeks depending on cultivar (Arendse et al., 2014).

Mphahlele et al. (2016) reported that commercially pomegranate fruits were packed in ventilated carton with polyliner referred to as passive modified atmosphere packaging (MAP), individual shrink wrap and open top carton (control) and stored under $7 \pm 0.5^{\circ} \mathrm{C}$ and $92 \pm 2 \% \quad \mathrm{RH}$ for 4 months. Incidence of physiological disorders and changes in biochemical properties, phenolic compounds, total phenols, total flavonoids, total tannins, total anthocyanins, antioxidant activity and vitamin $\mathrm{C}$ were analysed monthly. The results showed that fruits stored under polyliner and individual shrink wrapped significantly minimized weight loss compared to control. Amongst phenolic compounds identified, calcium and rutin increased in fruits packed inside polyliners and individual shrink wrap after 4 months. Total phenolic and total tannins declined in fruits stored under polyliner and individual shrink wrap after 3 months. Furthermore, total anthocyanin was significantly higher in fruits packed in MAP than individual shrink wrap fruits.

Among different elite horticultural practices, growth regulators have been used to increase fruit yield and fruit quality of applying $\mathrm{GA}_{3}$ on pomegranate plants to improve plant growth, yield, fruit quality parameters have been studied by Singh et al., 2003; Khalil and Aly, 2013 and Korkmaz et al., 2016.

Korkmaz et al. (2016) demonstrated that spraying calcium nitrate $(2 \%$ or $4 \%)$ and $\mathrm{GA}_{3}(50 \& 75 \mathrm{ppm})$ on pomegranate $\mathrm{cv}$. Hicaznar has been increased the fruit yield by both doses of calcium nitrate and the second dose of $\mathrm{GA}_{3}(75 \mathrm{ppm})$ in the $1^{\text {st }}$ year, while $\mathrm{GA}_{3}$ at $50 \mathrm{ppm}$ had an improving effect in the $2^{\text {nd }}$ year.

Currently, there is a trend towards healthier diets. Modified atmosphere packaging (MAP) is typically used for maintaining quality of fruits, mainly, healthier fruits such as pomegranate fruits. The use of MAP shows down physiological processes such as transpiration and respiration rate. Furthermore, relatively low oxygen concentration within the MAP may decrease the activity of the oxidizing enzymes (polyphneol oxidase, glycolic oxidase and ascorbic acid oxidase) meanwhile prolong the shelf life of stored fruits (Aries et al., 2000 and Arendse et al., 2014).

Selcuk and Erkan (2016) studied the effect of two different types of modified atmosphere packaging (MAP) on the physiochemical properties, biochemical composition and storage quality of sweet pomegranate cv. "Beynan" during long-term storage. they found that the MAPs significantly reduced weight loss and external physiological disorders, maintained visual quality and prevented the decline of skin colour. During storage period, $\mathrm{O}_{2}$ levels de- 
creased and $\mathrm{CO}_{2}$ levels increased inside the MAPs packaging compared to the control fruits.

Furthermore, MAP technology has been successfully used to maintain post-harvest quality and to prolong the storage period of many fruits. By creating higher $\mathrm{CO}_{2}$ and lower $\mathrm{O}_{2}$ concentration in the surrounding atmosphere of the fruits, decay, respiration rate, ethylene production and enzymatic activity can be controlled resulting in an increase in shelf life quality (Caleb et al., 2012 and Selak and Erkan, 2014, 2015).

Calcium $\left(\mathrm{Ca}^{2+}\right)$ has been extensively reviewed both as an essential element for its potential role in maintaining post harvest quality of fruits by contributing to the linkage between pectic substances within cell wall (Arhtas et al., 2010). It is also involved in reducing the rate of senescence and fruit ripening (White and Broadley, 2003; Mahajan and Dhatt, 2004 and Lara et al., 2004).

Therefore, the objective of this study was to examine the effects of pre-harvest spray with $\mathrm{GA}_{3} \& \mathrm{CaCl}_{2}$ and post harvest treatments with jasmine oil, olive oil, fiber gard and wrapping fruits and the combination of these treatments as modified atmosphere packaging of pomegranate fruit on physical and chemical characteristic under room temperature storage.

\section{Materials and Methods}

Two main experiments of this study were carried out during two successive seasons 2011 and 2012 on "Manfalouty" pomegranate cultivars grown at the experimental orchard of Pomology Department, Faculty of Agriculture, Assiut University.
Healthy trees and uniformely in growth were selected for this study. The trees age was approximately 35 years old at the beginning of the experiment and they were planted of $5 \times 5 \mathrm{~m}$ apart. As indicated before, the objectives of this investigation were to study 1) the effect of pre-harvest treatments with both $\mathrm{CaCl}_{2}$ and $\mathrm{GA}_{3}$ on some physical and chemical characteristics of pomegranate fruits. 2) the effect of these pre-harvest treatments on shelf life properties of pomegranate fruits during storage under room temperature. 3) the effect of post-harvest treatments with jasmine oil, olive oil, fiber gard and wrapping individually fruit with food polyolefin stretch and as well as the interactions between the pre-harvest and the post harvest treatments on fruit quality during storage under room temperature.

\section{The first experiment}

This experiment was conducted as field work to achieve the preharvest treatments as follows:

1- Untreated trees (sprayed with tap water) control fruits).

2- Sprayed trees with $100 \mathrm{ppm}$ $\mathrm{GA}_{3}$.

3- Sprayed trees with $4 \% \mathrm{CaCl}_{2}$.

Both $\mathrm{CaCl}_{2}(4 \%)$ or $\mathrm{GA}_{3}(100$ ppm) was sprayed twice time on the trees throughout the two studied seasons, the $1^{\text {st }}$ application time was two months $(2 / 6 / 2011$ and 2/6/2012 seasons) after fruit set of pomegranate trees and the $2^{\text {nd }}$ time of spraying was a month later of the $1^{\text {st }}$ application time.

\section{The second experiment:}

It was conducted to examine the effect of post-harvest treatments on physiological characteristics of 
pomegranate fruits under room temperature. The post-harvest treatments were carried out at the laboratory at Dept. of Pomology commercial ripe fruits were harvested and immediately were transported to the laboratory. After cleaning fruits and allowed to air dry, they were divided to five groups for storage under room temperature $\left(22 \pm 5^{\circ} \mathrm{C}\right)$ as follows:

1- Untreated fruits (control of stored fruits).

2- Dipping fruits in jasmine oil (2.5 $\mathrm{cm}^{3} / \mathrm{L}$ ).

3- Dipping fruits in olive oil $\left(2.5 \mathrm{~cm}^{3} / \mathrm{L}\right)$.

4-Dipping fruits in fiber gard $\left(20 \mathrm{~cm}^{3} / \mathrm{L}\right)$. Individually wrapping fruits with food polyolefin stretch.

Samples of the stored fruits bi weekly were taken for assessment the physical and chemical characteristics of fruits as follows:

1- Fruit weight (g).

2- Fruit peel (g)

3- Arils (pomegranate grains) whight (g)

\section{4- Fruit weight loss $\%$.}

The fruits of each replicate treatment were individually weighed before storage to get the initial weight (iw), then the sample fruit weight (sw) after each biweekly interval period of storage. Thereafter, the percentage of fruit weight loss was calculated according to the following equation:

Fruit weight loss $\%=\frac{\mathrm{iw}-\mathrm{sw}}{\mathrm{iw}} \times 100$

Where: iw $=$ initial fruit weight before storage

$\mathrm{sw}=$ fruit weight at the end of sample period.

5- Juice volume $\left(\mathrm{cm}^{3} / 100 \mathrm{ml} \mathrm{g}\right.$ of arils (pomegranate grains).

6- Total soluble solids \% (TSS\%)
The total soluble solids \% were determined using a hand refractometer.

7- Titratable acidity percentage (TA\%)

It was determined by titrating 10 $\mathrm{ml}$ juice with ph.ph. as an indicated against $1.0 \mathrm{~N} \mathrm{NaOH}$ and calculated as grams of citric acid/100 ml juice according to the method described in A.O.A.C. (2000).

8- Total soluble solids acid ratio (TSS/TA ratio). This ratio was determined by obtaining the ratio between total soluble solids and percentage of acidity.

9- Total sugar (reducing, nonreducing and total sugars) were determined using Lyne and Eynon methods as described in the A.O.A.C. (1975).

\section{Statistical analysis:}

The experiments were set up in split-split plot arrangements at two levels in complete randomized block design (CRBD) with three replicates, 20 fruits each, whereas, pre-harvest treatments were the whole plots (A), the $1^{\text {st }}$ level of splits was the post harvest treatments (B) and the $2^{\text {nd }}$ level of splits was the storage periods (C) according to Snedecor \& Cochran (1980) and Gomez \& Gomez (1984).

\section{Results and Discussion}

The obtained results of this research will focus on the effect of preharvest spraying with $\mathrm{GA}_{3}(100 \mathrm{ppm})$ and $\mathrm{CaCl}_{2}(4 \%)$ as well as the postharvest treatments with jasmine oil $\left(2.5 \mathrm{~cm}^{3} / \mathrm{L}\right)$, olive oil $\left(2.5 \mathrm{~cm}^{3} / \mathrm{L}\right)$, fiber gard $\left(20 \mathrm{~cm}^{3} / \mathrm{L}\right)$ and individually wrapping fruits with food polyolefen stretch (all the post-harvest treatments as modified atmosphere packaging of MAP of pomegranate fruits) 
Website: www.aun.edu.eg/faculty_agriculture/journals_issues_form.php E-mail:ajas@aun.edu.eg

on the physical and chemical characteristics of "Manfalouty" pomegranate fruits stored under room temperature during 2011 and 2012 seasons.

1- Effect of pre- and post-harvest treatments on some physical characteristics of pomegranate fruits stored under room temperature:

\section{1- Effect of fruit weight:}

Data presented in Table (1) indicated that the pre- and post-harvest treatments resulted in significant increase in fruit weight of Manfalouty pomegranate $\mathrm{cv}$., compared with untreated (control) fruits in 2011 and 2012.

Table 1. Effect of pre- and post-harvest treatments on fruit weight (g) of "Manfalouty" pomegranate cv. under room temperatures during 2011 and 2012 seasons.

\begin{tabular}{|c|c|c|c|c|c|c|c|c|c|}
\hline \multirow{3}{*}{$\begin{array}{c}\text { Pre-harvest } \\
\text { Treatments } \\
\text { A }\end{array}$} & \multirow{3}{*}{$\begin{array}{c}\text { Post-harvest } \\
\text { Treatments } \\
\text { B }\end{array}$} & \multicolumn{4}{|c|}{2011 season } & \multicolumn{4}{|c|}{2012 season } \\
\hline & & \multicolumn{3}{|c|}{ Periods C } & \multirow[b]{2}{*}{ Mean } & \multicolumn{3}{|c|}{ Periods C } & \multirow[b]{2}{*}{ Mean } \\
\hline & & $\begin{array}{l}\text { Zero } \\
\text { point }\end{array}$ & 1 & 2 & & $\begin{array}{l}\text { Zero } \\
\text { point }\end{array}$ & 1 & 2 & \\
\hline \multirow{6}{*}{ Control } & $\mathbf{O}$ & 301.8 & 287.2 & 248.8 & 279.3 & 516.7 & 386.7 & 345.3 & 416.2 \\
\hline & Jasmine oil & 366.9 & 319.9 & 301.7 & 329.5 & 474.8 & 371.9 & 332.1 & 392.9 \\
\hline & Olive oil & 363.4 & 326.8 & 267.1 & 319.1 & 479.7 & 375.4 & 311.7 & 388.9 \\
\hline & Fiber gard & 336.9 & 301.9 & 260.5 & 299.8 & 403.5 & 323.8 & 322.8 & 350.0 \\
\hline & Wrapping & 390.9 & 365.8 & 305.4 & 354.0 & 510.6 & 412.6 & 371.9 & 431.7 \\
\hline & Mean & 352.0 & 320.3 & 276.7 & 316.3 & 477.1 & 374.1 & 336.8 & 396.0 \\
\hline \multirow{6}{*}{$\begin{array}{c}\mathbf{G A}_{3}(100 \\
\text { ppm) }\end{array}$} & $\mathbf{O}$ & 421.7 & 377.1 & 297.0 & 365.3 & 645.4 & 497.0 & 478.6 & 540.3 \\
\hline & Jasmine oil & 398.3 & 360.7 & 277.4 & 345.5 & 772.2 & 634.6 & 573.6 & 660.1 \\
\hline & Olive oil & 457.8 & 423.8 & 294.8 & 392.1 & 845.4 & 688.9 & 586.9 & 707.1 \\
\hline & Fiber gard & 429.4 & 410.6 & 362.8 & 400.9 & 767.4 & 639.0 & 592.6 & 666.3 \\
\hline & Wrapping & 436.7 & 418.1 & 328.1 & 394.3 & 825.1 & 696.3 & 625.9 & 715.8 \\
\hline & Mean & 428.8 & 398.1 & 312.0 & 379.6 & 771.1 & 631.2 & 571.5 & 657.9 \\
\hline \multirow{6}{*}{$\mathrm{CaCl}_{2}(4 \%)$} & $\mathbf{O}$ & 347.8 & 312.2 & 255.3 & 305.1 & 600.3 & 456.4 & 421.0 & 492.6 \\
\hline & Jasmine oil & 388.1 & 351.3 & 223.5 & 321.0 & 553.4 & 425.9 & 353.3 & 444.2 \\
\hline & Olive oil & 360.5 & 335.1 & 262.1 & 319.2 & 600.1 & 490.0 & 463.3 & 517.8 \\
\hline & Fiber gard & 373.9 & 354.8 & 252.8 & 327.2 & 525.1 & 406.4 & 390.1 & 440.5 \\
\hline & Wrapping & 386.7 & 367.0 & 317.7 & 357.1 & 561.4 & 459.1 & 415.2 & 478.6 \\
\hline & Mean & 371.4 & 344.1 & 262.3 & 325.9 & 568.0 & 447.5 & 408.6 & 474.7 \\
\hline \multicolumn{2}{|c|}{ Mean } & 384.1 & 354.2 & 283.7 & & 605.4 & 484.3 & 439.0 & \\
\hline \multirow{5}{*}{ Mean } & $\mathbf{O}$ & 357.1 & 325.5 & 267.0 & 316.5 & 587.5 & 446.7 & 415.0 & 483.0 \\
\hline & Jasmine oil & 384.4 & 344.0 & 267.5 & 332.0 & 600.1 & 477.5 & 419.7 & 499.1 \\
\hline & Olive oil & 393.9 & 361.9 & 274.7 & 343.5 & 641.7 & 518.1 & 454.0 & 537.9 \\
\hline & Fiber gard & 380.1 & 355.8 & 292.0 & 342.6 & 565.3 & 456.4 & 435.2 & 485.6 \\
\hline & Wrapping & 404.8 & 383.6 & 317.1 & 368.5 & 632.4 & 522.7 & 471.0 & 542.0 \\
\hline
\end{tabular}

L.S.D. 0.05

A (Pre)

B (Post)

AB

C (Period)

AC

BC

ABC

\section{$=$}

$=$

$=$

$=$

$=$

$=$

$=$
13.5

17.5

30.2

13.5

23.4

n.s

n.s

Concerning, pre-harvest spraying with $\mathrm{GA}_{3}$ or $\mathrm{CaCl}_{2}$ on fruit weight, it was obviously that the group of fruits sprayed with $\mathrm{GA}_{3}$

19.5

25.1

43.5

19.5

n.s

n.s

n.s
(100 ppm) gave the heaviest fruit weight (428.8 \& $771.1 \mathrm{~g}$ ), followed by the group of fruits sprayed with $\mathrm{CaCl}_{2} 4 \%$ (371.4 \& $568.0 \mathrm{~g}$ ), then the 
group of untreated (control) fruits gave the lowest value of fruit weight $(352.0 \& 477.1 \mathrm{~g})$ in both season 2011 and 2012, respectively. As well as the pre-harvest treatment showed the same trend on the fruit weight at the end of storage period of stored fruits under room temperature during the two studied seasons, compared with untreated (control) fruits.

Within the group of untreated (control) fruits, wrapping fruits showed the heaviest fruit weight $(354.0 \& 431.7 \mathrm{~g})$, followed by treatment with jasmine oil $(329.5$ \& $392.9 \mathrm{~g}$ ), thereafter treatment with olive oil (319.1 \& $388.9 \mathrm{~g}$ ), then untreated fruits gave the highest fruit weight $(279.4 \& 416.2 \mathrm{~g})$ in season 2011 and 2012, respectively.

Within the group of fruits sprayed with $\mathrm{GA}_{3}$, wrapping fruits gave the highest value of fruit weight (394.3 \& $715.8 \mathrm{~g})$, while untreated fruits resulted in the lowest value of fruit weight $(365.4 \& 540.3 \mathrm{~g})$, in seasons 2011 and 2012, respectively.

Within the group of fruits sprayed with $\mathrm{CaCl}_{2}$, wrapping fruit induced the highest fruit weight $(357.1 \mathrm{~g})$ in the $1^{\text {st }}$ season, while treatment with olive oil resulted in the heaviest fruit weight $(517.8 \mathrm{~g})$ in the $2^{\text {nd }}$ season, followed by untreated fruits (492.6 g), compared with untreated fruits stored under room temperature.

In general, wrapping fruits resulted in the heaviest fruit weight, while untreated fruits showed the highest fruit weight as response to the effect of pre- and post-harvest treatments on pomegranate fruits stored under room temperature. The positive effects of pre-harvest spraying with $\mathrm{GA}_{3}$ or $\mathrm{CaCl}_{2}$ could be due to the pomotive effects of both of them on plant growth, increasing yield and fruit weight as found by Singh et al., 2003; Khalil and Aly, 2013 and Korkmaz et al., 2016).

\section{2- Effect of peel weight:}

Data recorded in Table (2) revealed that all pre- and post-harvest treatments induced significant effects on peel weight of Manfalouty pomegranate fruits during their shelf-life under room temperature in 2011 and 2012 seasons.

Concerning the effect of preharvest treatments on peel weight, it was clear that spraying $\mathrm{GA}_{3}(100$ ppm) resulted in heaviest peel weight (144.8 and $245.5 \mathrm{~g}$, respectively), followed by spraying $\mathrm{CaCl}_{2}$ (4\%) (125.0 \& $182.8 \mathrm{~g}$ ) in seasons 2011 and 2012, respectively, compared with untreated fruits.

Regarding to the effect of postharvest treatments on peel weight of pomegranate fruits under room temperature, it could be deduced that wrapping fruits gave the best treatments in both the group of untreated fruits and group of pre-harvest fruits sprayed with $\mathrm{CaCl}_{2}$, while spraying fiber gard on group of fruits sprayed with $\mathrm{GA}_{3}$ gave the best heaviest weight in season 2011, on the other hand, wrapping fruits in group of untreated fruits, as well as spraying olive oil gave of treated with $\mathrm{GA}_{3}$ and untreated fruits of gave of treated fruits with $\mathrm{CaCl}_{2}$ gave the best results under room temperature in season 2012. 
Table 2. Effect of pre- and post-harvest treatments on peel weight of "Manfalouty" pomegranate fruits under room temperatures during 2011 and 2012 seasons.

\begin{tabular}{|c|c|c|c|c|c|c|c|c|c|}
\hline \multirow{3}{*}{$\begin{array}{c}\text { Pre-harvest } \\
\text { Treatments } \\
\text { A }\end{array}$} & \multirow{3}{*}{$\begin{array}{c}\text { Post-harvest } \\
\text { Treatments } \\
\text { B }\end{array}$} & \multicolumn{4}{|c|}{2011 season } & \multicolumn{4}{|c|}{2012 season } \\
\hline & & \multicolumn{3}{|c|}{ Periods C } & \multirow[b]{2}{*}{ Mean } & \multicolumn{3}{|c|}{ Periods C } & \multirow[b]{2}{*}{ Mean } \\
\hline & & $\begin{array}{l}\text { Zero } \\
\text { point }\end{array}$ & 1 & 2 & & $\begin{array}{l}\text { Zero } \\
\text { point }\end{array}$ & 1 & 2 & \\
\hline \multirow{6}{*}{ Control } & $\mathbf{O}$ & 99.6 & 116.8 & 105.0 & 107.1 & 172.1 & 134.2 & 124.1 & 143.5 \\
\hline & Jasmin & 121.1 & 37.1 & 113.8 & 124.0 & 158.1 & 129.6 & 116.6 & 134.8 \\
\hline & (2) & 122.8 & 123.0 & 96.9 & & 145.5 & 119.5 & 115.2 & 6.7 \\
\hline & Fiber g & 112.2 & 117.0 & 114.5 & 114.6 & 143.8 & 112.1 & 103.1 & 19.7 \\
\hline & $\mathbf{W r}$ & 132.4 & 133.7 & 112.9 & 126.3 & 177.5 & 146.1 & 132.2 & 1.9 \\
\hline & Mean & 117.6 & 125.5 & 108.6 & 117.2 & 159.4 & 128.3 & 118.2 & 35.3 \\
\hline \multirow{6}{*}{$\begin{array}{c}\mathbf{G A}_{3}(100 \\
\text { ppm) }\end{array}$} & U & 142.3 & 138.4 & 108.9 & 129.9 & 207.5 & 168.0 & 155.1 & 176.9 \\
\hline & Jasmine oil & 135.4 & 146.4 & 115.6 & 132.5 & 251.8 & 188.8 & 162.5 & 201.0 \\
\hline & Olin & 154.6 & 169.8 & 112.0 & 145.5 & 274.6 & 195.8 & 166.8 & 212.4 \\
\hline & & 145.4 & 185.2 & 141.4 & 157.3 & 247.6 & 179.4 & 165.8 & 197.6 \\
\hline & & 146.3 & 185.5 & 119.8 & 150.5 & 246.1 & 205.5 & 179.1 & 210.2 \\
\hline & & 44.8 & 165.1 & 119.6 & 143.2 & 245.5 & 187.5 & 165.9 & 199.6 \\
\hline \multirow{6}{*}{$\mathrm{CaCl}_{2}(4 \%)$} & & 117.4 & 151.4 & 99.2 & 122.7 & 201.5 & 151.9 & 141.8 & 165.1 \\
\hline & Jasmine & 133.1 & 129.8 & 104.1 & 122.3 & 182.7 & 143.4 & 116.1 & 147.4 \\
\hline & Olive oil & 120.5 & 136.4 & 99.8 & 118.9 & 188.4 & 154.1 & 142.8 & 161.8 \\
\hline & Fiber gard & 124.6 & 131.9 & 96.1 & 117.5 & 165.8 & 136.6 & 130.8 & 144.4 \\
\hline & Wrapping & 129.6 & 135.2 & 125.3 & 130.0 & 175.3 & 153.9 & 151.8 & 160.3 \\
\hline & & 125.0 & 136.9 & 104.9 & 122.3 & 182.8 & 148.0 & 136.7 & 155.8 \\
\hline \multicolumn{2}{|c|}{ Mean } & 129.2 & 142.5 & 111.0 & & 195.9 & 154.6 & 140.3 & \\
\hline \multirow{5}{*}{ Mean } & & 119.8 & 135.5 & 104.4 & 119.9 & 193.7 & 151.4 & 140.3 & 161.8 \\
\hline & $\min$ & 129.9 & 137.8 & 111.2 & 126.3 & 197.5 & 153.9 & 131.7 & 161.1 \\
\hline & Olive oil & 132.6 & 143.1 & 102.9 & 126.2 & 202.8 & 156.5 & 141.6 & 167.0 \\
\hline & Fiber gard & 127.4 & 144.7 & 117.3 & 129.8 & 185.7 & 142.7 & 133.2 & 153.9 \\
\hline & Wrapping & 136.1 & 151.5 & 119.3 & 135.6 & 199.6 & 168.5 & 154.4 & 174.2 \\
\hline
\end{tabular}

L.S.D. 0.05
A (Pre) $\quad=$
6.6
$\mathrm{B}$ (Post) $=$
8.5
$\mathrm{C}($ Period $)=$
6.6
$\mathrm{AB}=$
14.7
$\mathrm{AC}=$
11.4
BC
$\mathrm{ABC}$
$=$
n.s
n.s

Generally, post-harvest treatments on the group of sprayed fruits with $\mathrm{GA}_{3}(100 \mathrm{ppm})$ as pre-harvest treatment gave the highest value of peel weight of fruits, followed by preharvest treatment with $\mathrm{CaCl}_{2}(4 \%)$, compared with untreated fruits during the two studied seasons.

The obtained results are in harmony with those reported by Jumaa and Ali (2016).
5.7
7.4
5.7
12.7
9.9
n.s
n.s

1.3- Effect of pre- and postharvest treatments on arils (pomegranate grains) weight:

According to data recorded in Table (3), it could be demonstrated that all pre- and post-harvest treatments induced significant increase in arils weight of pomegranate fruits during 2011 and 2012 seasons, compared to untreated fruits. 
Regarding to the effects of preharvest treatments on grain weight of pomegranate fruits, it could be deduced that pre-harvest spraying with $\mathrm{GA}_{3}(100 \mathrm{ppm})$ gave the heaviest grain weight (279.9 \& $519.6 \mathrm{~g})$, followed by pre-harvest spraying with $\mathrm{CaCl}_{2}$ (4\%) (248.1 \& $385.5 \mathrm{~g}$ ), compared with untreated fruits in 2011 and 2012 seasons, respectively.

Table 3. Effect of pre- and post-harvest treatments on arils weight of "Manfalouty" pomegranate fruits under room temperatures during 2011 and 2012 seasons.

\begin{tabular}{|c|c|c|c|c|c|c|c|c|c|}
\hline \multirow{3}{*}{$\begin{array}{c}\text { Pre-harvest } \\
\text { Treatments } \\
\text { A }\end{array}$} & \multirow{3}{*}{$\begin{array}{c}\text { Post-harvest } \\
\text { Treatments } \\
\text { B }\end{array}$} & \multicolumn{4}{|c|}{2011 season } & \multicolumn{4}{|c|}{2012 season } \\
\hline & & \multicolumn{3}{|c|}{ Periods C } & \multirow[b]{2}{*}{ Mean } & \multicolumn{3}{|c|}{ Periods C } & \multirow[b]{2}{*}{ Mean } \\
\hline & & $\begin{array}{l}\text { Zero } \\
\text { point }\end{array}$ & 1 & 2 & & $\begin{array}{l}\text { Zero } \\
\text { point }\end{array}$ & 1 & 2 & \\
\hline \multirow{6}{*}{ Control } & $\mathbf{O}$ & 202.1 & 170.1 & 143.8 & 172.0 & 344.6 & 252.5 & 221.2 & 272.8 \\
\hline & Jasmine oil & 245.8 & 182.8 & 187.9 & 205.5 & 316.7 & 242.3 & 215.5 & 258.2 \\
\hline & Olive oil & 240.6 & 203.9 & 170.2 & 204.9 & 336.3 & 255.9 & 196.5 & 262.9 \\
\hline & Fiber gard & 208.8 & 184.9 & 146.1 & 179.9 & 295.3 & 211.7 & 219.7 & 242.2 \\
\hline & Wrapping & 258.6 & 232.1 & 192.5 & 227.7 & 371.0 & 265.8 & 239.7 & 292.2 \\
\hline & Mean & 231.2 & 194.8 & 168.1 & 198.0 & 332.8 & 245.7 & 218.5 & 265.7 \\
\hline \multirow{6}{*}{$\begin{array}{c}\mathbf{G A}_{3}(100 \\
\text { ppm) }\end{array}$} & $\mathbf{O}$ & 279.3 & 238.7 & 188.1 & 235.4 & 437.9 & 329.0 & 323.4 & 363.4 \\
\hline & Jasmine oil & 262.9 & 214.3 & 161.8 & 213.0 & 520.4 & 445.9 & 411.1 & 459.1 \\
\hline & Olive oil & 283.2 & 254 & 182.8 & 240.0 & 540.9 & 493.1 & 420.1 & 484.7 \\
\hline & Fiber gard & 283.9 & 225.5 & 221.4 & 243.6 & 519.8 & 459.5 & 435.7 & 471.7 \\
\hline & Wrapping & 290.4 & 232.6 & 208.2 & 243.7 & 579.1 & 495.2 & 446.7 & 507.0 \\
\hline & Mean & 279.9 & 233.0 & 192.5 & 235.1 & 519.6 & 444.5 & 407.4 & 457.2 \\
\hline \multirow{6}{*}{$\mathrm{CaCl}_{2}(4 \%)$} & $\mathbf{O}$ & 230.4 & 160.8 & 156.1 & 182.4 & 398.8 & 304.5 & 279.2 & 327.5 \\
\hline & Jasmine oil & 261.7 & 221.5 & 119.3 & 200.8 & 370.7 & 282.4 & 237.2 & 296.8 \\
\hline & Olive oil & 240.0 & 198.8 & 163.6 & 200.8 & 412.8 & 336.3 & 320.5 & 356.5 \\
\hline & Fiber gard & 249.3 & 222.9 & 156.7 & 209.6 & 359.2 & 269.8 & 259.3 & 296.1 \\
\hline & Wrapping & 259.1 & 231.8 & 192.4 & 227.8 & 386.1 & 305.2 & 263.5 & 318.3 \\
\hline & Mean & 248.1 & 207.2 & 157.6 & 204.3 & 385.5 & 299.6 & 271.9 & 319.0 \\
\hline \multicolumn{2}{|c|}{ Mean } & 253.1 & 211.7 & 172.7 & & 412.6 & 329.9 & 299.3 & \\
\hline \multirow{5}{*}{ Mean } & $\mathbf{O}$ & 237.3 & 189.9 & 162.7 & 196.6 & 393.8 & 295.3 & 274.6 & 321.2 \\
\hline & Jasmine oil & 256.8 & 206.2 & 156.3 & 206.4 & 402.6 & 323.5 & 287.9 & 338.0 \\
\hline & Olive oil & 254.6 & 218.9 & 172.2 & 215.2 & 430.0 & 361.8 & 312.4 & 368.0 \\
\hline & Fiber gard & 247.3 & 211.1 & 174.7 & 211.1 & 391.4 & 313.7 & 304.9 & 336.7 \\
\hline & Wrapping & 269.4 & 232.2 & 197.7 & 233.1 & 445.4 & 355.4 & 316.6 & 372.5 \\
\hline \multicolumn{6}{|l|}{ L.S.D. 0.05 } & \\
\hline \multicolumn{2}{|c|}{ A (Pre) } & \multicolumn{4}{|c|}{11.3} & \multicolumn{4}{|c|}{15.4} \\
\hline \multicolumn{2}{|c|}{ B (Post) } & \multicolumn{4}{|c|}{14.5} & \multicolumn{4}{|c|}{19.9} \\
\hline \multicolumn{2}{|c|}{ C (Period) } & \multicolumn{4}{|c|}{11.3} & \multicolumn{4}{|c|}{15.4} \\
\hline \multicolumn{2}{|c|}{ AB } & \multicolumn{4}{|c|}{25.2} & \multicolumn{4}{|c|}{34.5} \\
\hline $\mathbf{A C}$ & $=$ & & & & & & n.s & & \\
\hline BC & $=$ & & & & & & n.s & & \\
\hline $\mathbf{A B C}$ & $=$ & & & & & & n.s & & \\
\hline
\end{tabular}

Concerning, the effect of postharvest treatments on grain weight, it could be observed that within the group of untreated fruits, post-harvest treatment with wrapping gave the best results $(227.7 \mathrm{~g})$, followed by dipping fruits in jasmine oil (205.5 g), thereafter spraying fruits with olive oil (204.9 g), than dipping fruits in fiber gard (179.9 g). Moreover, within the group of fruits sprayed with $\mathrm{GA}_{3}$, wrapping fruits gave the heaviest grain weight $(243.7 \mathrm{~g})$, followed by spraying fiber gard $(243.6$ 
g), thereafter spraying fruits with olive oil (240.0 g), then dipping fruits in jasmine oil $(213.0 \mathrm{~g})$, as well as within the group of fruits sprayed with $\mathrm{CaCl}_{2}(4 \%)$. The results showed the same trend of post-harvest treatment on the sprayed fruits with $\mathrm{GA}_{3}$, all results compared with untreated fruits in 2011 season. As well as, wrapping fruits of untreated fruits or sprayed fruits with $\mathrm{GA}_{3}$ as preharvest treatment showed the best treatment in 2012 seasons, while within the group of fruits sprayed with $\mathrm{CaCl}_{2}$, spraying fruits with olive oil gave the heaviest grain weight under room temperature.

Generally, the post-harvest treatment on the group of fruits sprayed with $\mathrm{GA}_{3}$ resulted in the best positive effects on arils weight of Manfalouty pomegranate fruits under room temperature during 2012 and 2012 seasons compared with untreated fruits.

All the obtained results could be attributed to the enhancement effects of pre-harvest treatment with spraying both $\mathrm{GA}_{3}$ or $\mathrm{CaCl}_{2}$ on increasing fruit weight, as well as increasing grain weight of fruits under the conditions of this study.

These obtained results are in parallel with those found by Mir et al. (1993).

\section{4- Effect of fruit weight loss \%:}

Data presented in Table (4) indicated that pre-harvest treatments with spraying $\mathrm{GA}_{3}(100 \mathrm{ppm})$ or $\mathrm{CaCl}_{2}(4 \%)$, as well as post-harvest treatments with jasmine oil, olive oil, fiber gard and wrapping fruits with food polyolefin stretch resulted in significant decrease in fruit weight loss $\%$ compared with untreated fruits during 2011 and 2012 seasons.

Concerning the response of preharvest treatments of pomegranate fruit weight loss $\%$ to the post-harvest treatments with jasmine oil, olive oil, fiber gard and wrapping fruits with food plastic stresh, it could be observed that the group of fruits sprayed with $\mathrm{CaCl}_{2}$ gave the least decrease in fruit weight loss \% $(15.17 \%$ \& $13.6 \%$ ), followed by the group of fruits sprayed with $\mathrm{GA}_{3}$ (15.93 \& $15.10 \%)$, then the group of untreated fruits (17.63 and $17.60 \%)$ in 2011 and 2012 seasons, respectively.

Within each group of preharvest treated or untreated fruits, it could be demonstrated that within the group of untreated fruits, wrapping fruits induced the least decrease in fruit weight loss $\%$, followed by dipping fruits with fiber gard, thereafter dipping fruits with olive oil, then dipping fruits with jasmine oil, as well as within both the groups of pre-harvest treated fruits with $\mathrm{GA}_{3}$ or $\mathrm{CaCl}_{2}$ took the same trend of the untreated preharvest fruits during the two studied seasons.

These obtained results could be due to the positive effects of preharvest treatments with $\mathrm{GA}_{3}$ or $\mathrm{CaCl}_{2}$ on improving fruit quality of Manfalouty pomegranate $\mathrm{cv}$. under the condition of this study.

These obtained results are in accordance with those finding reported by Nanda et al. (2001). 
Table 4. Effect of pre- and post-harvest treatments on weight loss \% of "Manfalouty" pomegranate fruits under room temperatures during 2011 and 2012 seasons.

\begin{tabular}{|c|c|c|c|c|c|c|c|c|c|}
\hline \multirow{3}{*}{$\begin{array}{c}\text { Pre-harvest } \\
\text { Treatments } \\
\text { A }\end{array}$} & \multirow{3}{*}{$\begin{array}{c}\text { Post-harvest } \\
\text { Treatments } \\
\text { B }\end{array}$} & \multicolumn{4}{|c|}{2011 season } & \multicolumn{4}{|c|}{2012 season } \\
\hline & & \multicolumn{3}{|c|}{ Periods C } & \multirow[b]{2}{*}{ Mean } & \multicolumn{3}{|c|}{ Periods C } & \multirow[b]{2}{*}{ Mean } \\
\hline & & $\begin{array}{l}\text { Zero } \\
\text { point }\end{array}$ & 1 & 2 & & $\begin{array}{l}\text { Zero } \\
\text { point }\end{array}$ & 1 & 2 & \\
\hline \multirow{6}{*}{ Control } & $\mathbf{O}$ & 0.00 & 24.57 & 39.88 & 21.48 & 0.000 & 24.630 & 37.470 & 20.700 \\
\hline & Jasmine oil & 0.00 & 20.78 & 34.91 & 18.56 & 0.000 & 21.920 & 33.110 & 18.343 \\
\hline & Olive oil & 0.00 & 21.98 & 31.50 & 17.83 & 0.000 & 21.300 & 32.460 & 17.920 \\
\hline & Fiber gard & 0.00 & 19.90 & 27.25 & 15.72 & 0.000 & 20.830 & 28.000 & 16.277 \\
\hline & Wrapping & 0.00 & 19.00 & 24.75 & 14.58 & 0.000 & 17.670 & 26.260 & 14.643 \\
\hline & Mean & 0.00 & 21.20 & 31.70 & 17.63 & 0.000 & 21.300 & 31.500 & 17.600 \\
\hline \multirow{6}{*}{$\begin{array}{c}\mathbf{G A}_{3}(100 \\
\mathbf{p p m})\end{array}$} & $\mathbf{O}$ & 0.00 & 23.31 & 35.35 & 19.55 & 0.000 & 21.580 & 33.830 & 18.470 \\
\hline & Jasmine oil & 0.00 & 21.33 & 29.87 & 17.07 & 0.000 & 19.080 & 26.220 & 15.100 \\
\hline & Olive oil & 0.00 & 19.33 & 26.47 & 15.27 & 0.000 & 20.000 & 26.170 & 15.390 \\
\hline & Fiber gard & 0.00 & 17.20 & 25.57 & 14.26 & 0.000 & 17.500 & 23.930 & 13.810 \\
\hline & Wrapping & 0.00 & 16.13 & 24.07 & 13.40 & 0.000 & 16.590 & 21.250 & 12.613 \\
\hline & Mean & 0.00 & 19.50 & 28.30 & 15.93 & 0.000 & 19.000 & 26.300 & 15.100 \\
\hline \multirow{6}{*}{$\mathrm{CaCl}_{2}(4 \%)$} & $\mathbf{O}$ & 0.00 & 22.78 & 34.18 & 18.99 & 0.000 & 20.300 & 31.820 & 17.373 \\
\hline & Jasmine oil & 0.00 & 20.63 & 31.15 & 17.26 & 0.000 & 18.180 & 23.000 & 13.727 \\
\hline & Olive oil & 0.00 & 18.54 & 25.15 & 14.56 & 0.000 & 17.170 & 22.810 & 13.327 \\
\hline & Fiber gard & 0.00 & 17.14 & 22.22 & 13.12 & 0.000 & 16.170 & 21.320 & 12.497 \\
\hline & Wrapping & 0.00 & 15.83 & 19.87 & 11.90 & 0.000 & 14.270 & 19.100 & 11.123 \\
\hline & Mean & 0.00 & 19.00 & 26.50 & 15.17 & 0.000 & 17.200 & 23.600 & 13.600 \\
\hline \multicolumn{2}{|c|}{ Mean } & 0.00 & 19.90 & 28.82 & & 0.000 & 19.149 & 27.119 & \\
\hline \multirow{5}{*}{ Mean } & $\mathbf{O}$ & 0.00 & 23.55 & 36.47 & 20.01 & 0.000 & 22.170 & 34.373 & 18.848 \\
\hline & Jasmine oil & 0.00 & 20.91 & 31.98 & 17.63 & 0.000 & 19.727 & 27.443 & 15.723 \\
\hline & Olive oil & 0.00 & 19.95 & 27.71 & 15.89 & 0.000 & 19.490 & 27.147 & 15.546 \\
\hline & Fiber gard & 0.00 & 18.08 & 25.01 & 14.36 & 0.000 & 18.167 & 24.417 & 14.194 \\
\hline & Wrapping & 0.00 & 16.99 & 22.90 & 13.29 & 0.000 & 16.177 & 22.203 & 12.793 \\
\hline \multicolumn{6}{|l|}{ L.S.D. 0.05} & \\
\hline A (Pre) & $=$ & \multicolumn{4}{|c|}{0.42} & \multicolumn{4}{|c|}{0.491} \\
\hline B (Post & $=$ & \multicolumn{4}{|c|}{0.55} & \multicolumn{4}{|c|}{0.634} \\
\hline C (Peri & od) & \multicolumn{4}{|c|}{0.42} & \multicolumn{4}{|c|}{0.491} \\
\hline $\mathbf{A B}$ & $=$ & \multicolumn{4}{|c|}{ n.s } & \multicolumn{4}{|c|}{ n.s } \\
\hline $\mathbf{A C}$ & $=$ & \multicolumn{4}{|c|}{0.74} & \multicolumn{4}{|c|}{0.850} \\
\hline BC & $=$ & \multicolumn{4}{|c|}{0.95} & \multicolumn{4}{|c|}{1.10} \\
\hline $\mathbf{A B C}$ & $=$ & & 1. & & & & n.s & & \\
\hline
\end{tabular}

1.5- Effect of pre- and post harvest treatments on juice volume (ml/100 g arils) (pomegranate grains):

As pointed out in Table (5) it was clear that pre-harvest treatments with $\mathrm{CaCl}_{2}(4 \%)$ and $\mathrm{GA}_{3}(100 \mathrm{ppm})$, as well as post-harvest treatments with jamine oil, olive oil, fiber gard and individually wrapped fruit with food polyolfen stretch induced significantly increase in juice volume (g/100 g arils), during shelf-life period of storage pomegranate fruits under room temperature, compared with untreated fruits in 2011 and 2012 seasons.

Concerning, the effect of preharvest treatments on juice volume of pomegranate fruit, it could be noticed that spraying $\mathrm{GA}_{3}(100 \mathrm{ppm})$ gave the highest value of juice volume $(71.9 \&$ $71.0 \mathrm{ml}$ ), followed by spraying $\mathrm{CaCl}_{2}$ (4\%) $(70.9 \& 69.1 \mathrm{ml})$ then the untreated fruits $(68.0 \& 63.5 \mathrm{ml})$ during 2011 and 2012 seasons, respectively.

Regard to the effect of post-harvest treatments on juice volume it was clear that the group of fruits sprayed with 
$\mathrm{GA}_{3}$, in response to the post-harvest treatment, resulted in the heaviest juice volume $(70.43 \& 62.27 \mathrm{ml})$, followed by the group of fruits sprayed with $\mathrm{CaCl}_{2}$ $(69.30 \& 61.67 \mathrm{ml})$, then the group of untreated fruits $(65.27 \& 58.17 \mathrm{ml})$, in 2011 and 2012 seasons, respectively.

Within each group of fruits treated with the tested post-harvest treatments, it could be deduced that in the group of untreated fruits wrapping fruits gave the highest value of juice volume, followed by fiber gard, thereafter olive oil, then untreated fruits with post-harvest treatment and jasmine oil gave the lowest value of juice volume in the $1^{\text {st }}$ season, while in the $2^{\text {nd }}$ season of storage fruits, all the post-harvest treatments showed the same trend of the $1^{\text {st }}$ season except the treatment with jasmine oil indicate an improving of juice volume than the untreated fruits.

Within the group of fruits sprayed with $\mathrm{GA}_{3}$, it was obviously that storage fruits under room temperature, treated fruits with fiber gard gave the highest value of juice volume, followed by wrapping fruits, thereafter treatment with olive oil, then jasmine oil compared with untreated fruits with post harvest treatments in both studied seasons.

Within the group of fruits sprayed with $\mathrm{CaCl}_{2}$, all the post-harvest treatments improved juice volume during the two seasons, moreover, wrapping fruits gave the highest value of juice volume in the $1^{\text {st }}$ season, while, fiber gard treatments gave the highest value of juice volume in the $2^{\text {nd }}$ season, followed by treatment with both of jasmine oil or olive oil during 2011 and 2012 seasons.

These positive effects of the postharvest treatments could be due to reducing moisture loss in response to the modified atmosphere surrounding the treated fruits stored under room temperature, compared to the untreated fruits.

These obtained results are in harmony with those found by Higazi et al. (1983). 
Table 9. Effect of pre- and post-harvest treatments on juice volume $(\mathrm{ml} / 100 \mathrm{~g})$ of "Manfalouty" pomegranate fruits under room temperatures during 2011 and 2012 seasons.

\begin{tabular}{|c|c|c|c|c|c|c|c|c|c|}
\hline \multirow{3}{*}{$\begin{array}{c}\text { Pre-harvest } \\
\text { Treatments } \\
\text { A }\end{array}$} & \multirow{3}{*}{$\begin{array}{c}\text { Post-harvest } \\
\text { Treatments } \\
\text { B }\end{array}$} & \multicolumn{4}{|c|}{2011 season } & \multicolumn{4}{|c|}{2012 season } \\
\hline & & \multicolumn{3}{|c|}{ Periods C } & \multirow[b]{2}{*}{ Mean } & \multicolumn{3}{|c|}{ Periods C } & \multirow[b]{2}{*}{ Mean } \\
\hline & & $\begin{array}{l}\text { Zero } \\
\text { point }\end{array}$ & 1 & 2 & & $\begin{array}{l}\text { Zero } \\
\text { point }\end{array}$ & 1 & 2 & \\
\hline \multirow{6}{*}{ Control } & $\mathbf{O}$ & 67.67 & 63.00 & 61.33 & 64.00 & 64.33 & 52.33 & 50.00 & 55.55 \\
\hline & Jasmine oil & 65.00 & 62.67 & 59.00 & 62.22 & 62.33 & 55.67 & 49.67 & 55.89 \\
\hline & Olive oil & 70.00 & 63.67 & 61.67 & 65.11 & 59.00 & 57.33 & 52.33 & 56.22 \\
\hline & Fiber gard & 68.33 & 66.67 & 66.00 & 67.00 & 65.33 & 58.00 & 54.67 & 59.33 \\
\hline & Wrapping & 69.00 & 67.67 & 67.33 & 68.00 & 66.33 & 65.00 & 59.67 & 63.67 \\
\hline & Mean & 68.00 & 64.70 & 63.10 & 65.27 & 63.50 & 57.70 & 53.30 & 58.17 \\
\hline \multirow{6}{*}{$\begin{array}{c}\mathbf{G A}_{3}(100 \\
\text { ppm) }\end{array}$} & $\mathbf{O}$ & 71.00 & 70.00 & 67.00 & 69.33 & 69.33 & 56.67 & 54.67 & 60.22 \\
\hline & Jasmine oil & 71.00 & 71.33 & 67.33 & 69.89 & 69.67 & 54.67 & 52.33 & 58.89 \\
\hline & Olive oil & 73.00 & 69.67 & 68.67 & 70.45 & 70.67 & 61.33 & 57.33 & 63.11 \\
\hline & Fiber gard & 73.33 & 72.33 & 70.00 & 71.89 & 72.33 & 63.67 & 60.00 & 65.33 \\
\hline & Wrapping & 71.00 & 70.00 & 70.67 & 70.56 & 73.00 & 61.33 & 57.00 & 63.78 \\
\hline & Mean & 71.90 & 70.70 & 68.70 & 70.43 & 71.00 & 59.50 & 56.30 & 62.27 \\
\hline \multirow{6}{*}{$\mathrm{CaCl}_{2}(4 \%)$} & $\mathbf{O}$ & 70.00 & 68.67 & 66.00 & 68.22 & 68.00 & 60.33 & 55.67 & 61.33 \\
\hline & Jasmine oil & 70.67 & 69.33 & 67.00 & 69.00 & 69.67 & 62.33 & 51.33 & 61.11 \\
\hline & Olive oil & 70.67 & 69.33 & 67.00 & 69.00 & 69.33 & 58.33 & 54.67 & 60.78 \\
\hline & Fiber gard & 71.33 & 70.33 & 67.67 & 69.78 & 69.00 & 61.67 & 57.33 & 62.67 \\
\hline & Wrapping & 71.67 & 70.33 & 69.33 & 70.44 & 69.67 & 60.33 & 57.33 & 62.44 \\
\hline & Mean & 70.90 & 69.60 & 67.40 & 69.30 & 69.10 & 60.60 & 55.30 & 61.67 \\
\hline \multicolumn{2}{|c|}{ Mean } & 70.25 & 68.33 & 66.40 & & 67.87 & 59.27 & 54.94 & \\
\hline \multirow{5}{*}{ Mean } & $\mathbf{O}$ & 69.56 & 67.22 & 64.78 & 67.19 & 67.22 & 56.44 & 53.45 & 59.04 \\
\hline & Jasmine oil & 68.89 & 67.78 & 64.44 & 67.04 & 67.22 & 57.56 & 51.11 & 58.63 \\
\hline & Olive oil & 71.22 & 67.56 & 65.78 & 68.19 & 66.33 & 59.00 & 54.78 & 60.04 \\
\hline & Fiber gard & 71.00 & 69.78 & 67.89 & 69.55 & 68.89 & 61.11 & 57.33 & 62.44 \\
\hline & Wrapping & 70.56 & 69.33 & 69.11 & 69.67 & 69.67 & 62.22 & 58.00 & 63.30 \\
\hline \multicolumn{10}{|l|}{ L.S.D. 0.05} \\
\hline \multicolumn{2}{|l|}{ B (Post) } & \multicolumn{4}{|c|}{0.9} & \multicolumn{4}{|c|}{1.192} \\
\hline \multirow{2}{*}{\multicolumn{2}{|c|}{$\begin{array}{l}\text { B (Post) } \\
\text { C (Period) }\end{array}$}} & \multicolumn{4}{|c|}{1.2} & \multicolumn{4}{|c|}{1.539} \\
\hline & & \multicolumn{4}{|c|}{0.9} & \multicolumn{4}{|c|}{1.192} \\
\hline $\mathbf{A B}$ & $=$ & \multicolumn{4}{|c|}{2.1} & \multicolumn{4}{|c|}{2.666} \\
\hline AC & $=$ & \multicolumn{4}{|c|}{ n.s } & \multicolumn{4}{|c|}{2.065} \\
\hline BC & $=$ & & n. & & & & n.s & & \\
\hline $\mathbf{A B C}$ & $=$ & & n. & & & & n.s & & \\
\hline
\end{tabular}

2- Effect of pre- and post-harvest treatments on some chemical characteristics of pomegranate fruits:

\section{1- Effects on TSS\%:}

Data recorded in Table (6) showed that both of pre-harvest treatments with $\mathrm{GA}_{3}$ and $\mathrm{CaCl}_{2}$ or post-harvest treatment with jasmine oil, olive oil, fiber gard and individually wrapping fruit with food polyolfen stretch resulted in significant effects on TSS $\%$ in juice of Manfalouty pomegranate fruits during shelf-life period under room temperature in 2011 and 2012 seasons.

Regard to, the effect of pre-harvest spraying with $\mathrm{GA}_{3}(100 \mathrm{ppm})$ and $\mathrm{CaCl}_{2}$ $(4 \%)$, it was obviously that spraying $\mathrm{GA}_{3}$ gave the highest value of $\mathrm{TSS} \%$ in fruit juice during the $1^{\text {st }}$ season, on the other hand $\mathrm{GA}_{3}$ treatments gave the lowest value of $\mathrm{TSS} \%$ in fruit juice in the $2^{\text {nd }}$ season, while spraying $\mathrm{CaCl}_{2}$ gave the lowest value of $\mathrm{TSS} \%$ in fruit juice at the $1^{\text {st }}$ season and gave the highest value of $\mathrm{TSS} \%$ in the $2^{\text {nd }}$ season, all results were compared with untreated fruits. The positive or negative effects of preharvest treatments with $\mathrm{GA}_{3}$ or $\mathrm{CaCl}_{2}$ on $\mathrm{TSS} \%$ in juice could be attributed with the effects of $\mathrm{GA}_{3}$ or $\mathrm{CaCl}_{2}$ on delaying fruit ripening stages during the two studied seasons.

Concerning the effect of postharvest treatments with jasmine oil, olive 
oil, fiber gard and wrapping fruits on $\mathrm{TSS} \%$ in fruit juice during shelf life period under room temperature, it could be deduced that group of untreated preharvest treatments gave the highest value of TSS\% in fruit juice during the 2 studied seasons. Thus should be due to more moisture loss of untreated fruits comparing with treated fruits as modified atmosphere packaging surrounding the fruits stored under room temperature.

Within each group of fruits treated with pre-harvest treatments, untreated fruits with the post-harvest treatments resulted in the highest value of $\mathrm{TSS} \%$ in fruit juice during the $1^{\text {st }}$ season, followed by wrapping fruits in the group of untreated fruits or the group of sprayed fruits with $\mathrm{GA}_{3}$ and dipping fruits in olive oil within the group of treated fruits with $\mathrm{CaCl}_{2}$ during the $1^{\text {st }}$ season. During storage fruits in the $2^{\text {nd }}$ seasons, it was noticed that untreated fruits with post-harvest treatments gave the highest value of TSS\%, followed by jasmine oil treatment, while in the group of treated fruits with $\mathrm{GA}_{3}$, jasmine oil treatment gave the highest value of $\mathrm{TSS} \%$, followed by fiber gard, moreover, fiber gard also gave the highest value of $\mathrm{TSS} \%$ in the group of fruits treated with $\mathrm{CaCl}_{2}$ followed by jasmine oil treatments in 2011 and 2012 seasons.

These obtained results are in agreement with those reported by Samar et al. (2016).

Table 6. Effect of pre- and post-harvest treatments on T.S.S.\% in juice of "Manfalouty" pomegranate fruits under room temperatures during 2011 and 2012 seasons.

\begin{tabular}{|c|c|c|c|c|c|c|c|c|c|}
\hline \multirow{3}{*}{$\begin{array}{c}\text { Pre-harvest } \\
\text { Treatments } \\
\text { A }\end{array}$} & \multirow{3}{*}{$\begin{array}{c}\text { Post-harvest } \\
\text { Treatments } \\
\text { B }\end{array}$} & \multicolumn{4}{|c|}{2011 season } & \multicolumn{4}{|c|}{2012 season } \\
\hline & & \multicolumn{3}{|c|}{ Periods C } & \multirow[b]{2}{*}{ Mean } & \multicolumn{3}{|c|}{ Periods C } & \multirow[b]{2}{*}{ Mean } \\
\hline & & $\begin{array}{l}\text { Zero } \\
\text { point }\end{array}$ & 1 & 2 & & $\begin{array}{l}\text { Zero } \\
\text { point }\end{array}$ & 1 & 2 & \\
\hline \multirow{6}{*}{ Control } & $\mathbf{O}$ & 16.73 & 17.33 & 18.13 & 17.40 & 16.00 & 16.93 & 17.87 & 16.93 \\
\hline & Jasmine oil & 16.33 & 16.67 & 17.40 & 16.80 & 16.07 & 16.87 & 17.80 & 16.91 \\
\hline & Olive oil & 16.20 & 17.00 & 17.13 & 16.78 & 15.80 & 16.40 & 17.47 & 16.56 \\
\hline & Fiber gard & 16.00 & 17.13 & 17.07 & 16.73 & 15.93 & 16.60 & 16.80 & 16.44 \\
\hline & Wrapping & 16.20 & 17.27 & 17.27 & 16.91 & 16.13 & 16.80 & 17.00 & 16.64 \\
\hline & Mean & 16.30 & 17.10 & 17.40 & 16.93 & 16.00 & 16.70 & 17.40 & 16.70 \\
\hline \multirow{6}{*}{$\begin{array}{c}\mathbf{G A}_{3}(100 \\
\text { ppm) }\end{array}$} & $\mathbf{O}$ & 16.93 & 17.00 & 17.27 & 17.07 & 15.47 & 16.07 & 17.13 & 16.22 \\
\hline & Jasmine oil & 16.73 & 16.87 & 16.73 & 16.78 & 16.00 & 16.53 & 17.00 & 16.51 \\
\hline & Olive oil & 16.40 & 16.53 & 16.67 & 16.53 & 15.53 & 16.13 & 16.87 & 16.18 \\
\hline & Fiber gard & 16.20 & 16.93 & 17.13 & 16.75 & 15.67 & 16.20 & 16.93 & 16.27 \\
\hline & Wrapping & 16.27 & 17.07 & 17.27 & 16.87 & 15.67 & 15.93 & 16.87 & 16.16 \\
\hline & Mean & 16.50 & 16.90 & 17.00 & 16.80 & 15.70 & 16.20 & 17.00 & 16.30 \\
\hline \multirow{6}{*}{$\mathrm{CaCl}_{2}(4 \%)$} & $\mathbf{O}$ & 16.40 & 16.67 & 17.67 & 16.91 & 16.13 & 16.40 & 16.87 & 16.47 \\
\hline & Jasmine oil & 16.13 & 16.60 & 17.13 & 16.62 & 16.33 & 16.87 & 16.93 & 16.71 \\
\hline & Olive oil & 16.13 & 17.07 & 17.27 & 16.82 & 16.20 & 16.13 & 17.40 & 16.58 \\
\hline & Fiber gard & 16.00 & 16.27 & 17.07 & 16.45 & 16.27 & 16.93 & 17.27 & 16.82 \\
\hline & Wrapping & 15.80 & 16.20 & 16.80 & 16.27 & 16.13 & 16.40 & 16.87 & 16.47 \\
\hline & Mean & 16.10 & 16.60 & 17.20 & 16.63 & 16.20 & 16.50 & 17.10 & 16.60 \\
\hline \multicolumn{2}{|c|}{ Mean } & 16.30 & 16.85 & 17.20 & & 15.96 & 16.48 & 17.14 & \\
\hline \multirow{5}{*}{ Mean } & $\mathbf{O}$ & 16.69 & 17.00 & 17.69 & 17.13 & 15.87 & 16.47 & 17.29 & 16.54 \\
\hline & Jasmine oil & 16.40 & 16.71 & 17.09 & 16.73 & 16.13 & 16.76 & 17.24 & 16.71 \\
\hline & Olive oil & 16.24 & 16.87 & 17.02 & 16.71 & 15.84 & 16.22 & 17.25 & 16.44 \\
\hline & Fiber gard & 16.07 & 16.78 & 17.09 & 16.64 & 15.96 & 16.58 & 17.00 & 16.51 \\
\hline & Wrapping & 16.09 & 16.85 & 17.11 & 16.68 & 15.98 & 16.38 & 16.91 & 16.42 \\
\hline \multicolumn{6}{|l|}{ L.S.D. 0.05} & \\
\hline \multirow{2}{*}{\multicolumn{2}{|c|}{$\begin{array}{l}\text { A (Pre) } \\
\text { B (Post) }\end{array}$}} & \multicolumn{4}{|c|}{0.15} & \multicolumn{4}{|c|}{0.194} \\
\hline & & \multicolumn{4}{|c|}{0.20} & \multicolumn{4}{|c|}{ n.s } \\
\hline \multicolumn{2}{|c|}{ C (Period) } & \multicolumn{4}{|c|}{0.15} & \multicolumn{4}{|c|}{0.194} \\
\hline $\mathbf{A B}$ & $=$ & \multicolumn{4}{|c|}{0.34} & \multicolumn{4}{|c|}{ n.s } \\
\hline AC & $=$ & \multicolumn{4}{|c|}{0.26} & \multicolumn{4}{|c|}{ n.s } \\
\hline BC & $=$ & & n. & & & & n.s & & \\
\hline $\mathrm{ABC}$ & $=$ & & $\mathrm{n}$. & & & & n.s & & \\
\hline
\end{tabular}


2.2- Effect on titratable acidity \%:

Data presented in Table (7) indicated that all pre-harvest treatments with $\mathrm{GA}_{3}$ or $\mathrm{CaCl}_{2}$ and the postharvest treatments with jasmine oil, olive oil, fiber gard and wrapping fruits induced significantly increase in the titratable acidity $\%$ (as g citric acid, TA\%) in fruit juice of Manfalouty pomegranate cv. compared with untreated fruits in 2011 and 2012 seasons.

Table 7. Effect of pre- and post-harvest treatments on titratable acidity \% (TA\%) in juice of "Manfalouty" pomegranate fruits under room temperatures during 2011 and 2012 seasons.

\begin{tabular}{|c|c|c|c|c|c|c|c|}
\hline \multirow{3}{*}{$\begin{array}{c}\text { Pre-harvest } \\
\text { Treatments } \\
\text { A }\end{array}$} & \multirow{3}{*}{$\begin{array}{c}\text { Post-harvest } \\
\text { Treatments } \\
\text { B }\end{array}$} & \multicolumn{4}{|c|}{2011 season } & \multirow{2}{*}{\multicolumn{2}{|c|}{\begin{tabular}{|c|}
2012 se \\
Periods C
\end{tabular}}} \\
\hline & & \multicolumn{3}{|c|}{ Periods C } & \multirow[b]{2}{*}{ Mean } & & \\
\hline & & $\begin{array}{l}\text { Zero } \\
\text { point }\end{array}$ & 1 & 2 & & $\begin{array}{l}\text { Zero } \\
\text { point }\end{array}$ & 1 \\
\hline \multirow{6}{*}{ Control } & $\mathbf{O}$ & 1.473 & 1.407 & 1.250 & 1.377 & 1.360 & 1.283 \\
\hline & Jasmine oil & 1.560 & 1.530 & 1.397 & 1.496 & 1.683 & 1.663 \\
\hline & Olive oil & 1.567 & 1.460 & 1.403 & 1.477 & 1.590 & 1.710 \\
\hline & Fiber gard & 1.647 & 1.513 & 1.380 & 1.513 & 1.437 & 1.410 \\
\hline & Wrapping & 1.550 & 1.457 & 1.323 & 1.443 & 1.847 & 1.823 \\
\hline & Mean & 1.600 & 1.500 & 1.400 & 1.500 & 1.600 & 1.600 \\
\hline \multirow{6}{*}{$\begin{array}{c}\mathbf{G A}_{3}(100 \\
\mathbf{p p m})\end{array}$} & $\mathbf{O}$ & 1.780 & 1.757 & 1.603 & 1.713 & 1.777 & 1.730 \\
\hline & Jasmine oil & 1.697 & 1.663 & 1.457 & 1.606 & 1.650 & 1.667 \\
\hline & Olive oil & 1.710 & 1.653 & 1.450 & 1.604 & 1.933 & 1.930 \\
\hline & Fiber gard & 1.787 & 1.710 & 1.567 & 1.688 & 1.760 & 1.740 \\
\hline & Wrapping & 1.737 & 1.723 & 1.673 & 1.711 & 1.887 & 1.863 \\
\hline & Mean & 1.700 & 1.700 & 1.600 & 1.667 & 1.800 & 1.800 \\
\hline \multirow{6}{*}{$\mathrm{CaCl}_{2}(4 \%)$} & $\mathbf{O}$ & 1.707 & 1.650 & 1.637 & 1.665 & 1.787 & 1.747 \\
\hline & Jasmine oil & 1.850 & 1.800 & 1.613 & 1.754 & 1.927 & 1.870 \\
\hline & Olive oil & 1.767 & 1.720 & 1.633 & 1.707 & 1.947 & 1.983 \\
\hline & Fiber gard & 1.717 & 1.670 & 1.607 & 1.665 & 2.100 & 2.050 \\
\hline & Wrapping & 1.717 & 1.710 & 1.663 & 1.697 & 2.083 & 2.033 \\
\hline & Mean & 1.800 & 1.700 & 1.600 & 1.700 & 2.000 & 1.900 \\
\hline \multicolumn{2}{|c|}{ Mean } & 1.687 & 1.629 & 1.514 & & 1.787 & 1.767 \\
\hline \multirow{5}{*}{ Mean } & $\mathbf{O}$ & 1.653 & 1.605 & 1.497 & 1.585 & 1.641 & 1.587 \\
\hline & Jasmine oil & 1.702 & 1.664 & 1.489 & 1.619 & 1.753 & 1.733 \\
\hline & Olive oil & 1.681 & 1.611 & 1.495 & 1.596 & 1.823 & 1.874 \\
\hline & Fiber gard & 1.717 & 1.631 & 1.518 & 1.622 & 1.766 & 1.733 \\
\hline & Wrapping & 1.668 & 1.630 & 1.553 & 1.617 & 1.939 & 1.906 \\
\hline \multicolumn{6}{|l|}{ L.S.D. 0.05} & & \\
\hline A (Pre) & $=$ & \multicolumn{4}{|c|}{0.030} & & 0.069 \\
\hline B (Post & $=$ & \multicolumn{4}{|c|}{0.039} & & 0.089 \\
\hline C (Peri & d) & \multicolumn{4}{|c|}{0.030} & & 0.069 \\
\hline $\mathbf{A B}$ & $=$ & \multicolumn{4}{|c|}{0.067} & & 0.154 \\
\hline $\mathbf{A C}$ & $=$ & \multicolumn{4}{|c|}{ n.s } & & n.s \\
\hline BC & $=$ & \multicolumn{4}{|c|}{ n.s } & & n.s \\
\hline $\mathrm{ABC}$ & $=$ & \multicolumn{4}{|c|}{ n.s } & & n.s \\
\hline
\end{tabular}

Concerning the effect of preharvest spraying with $\mathrm{GA}_{3}$ and $\mathrm{CaCl}_{2}$ on pomegranate trees, it could be revealed that spraying $\mathrm{CaCl}_{2}$ resulted in the highest percentage of the titratable acidity (TA\%) in fruit juice $(1.8$
\& $2.0 \%)$, followed by $\mathrm{GA}_{3}(1.7 \&$ $1.8 \%)$, then the untreated fruits $(1.6$ $\& 1.6 \%$ ) in 2011 and 2012 seasons, respectively.

Within the group of untreated fruits (the control group) treatment 
with fiber gard gave the highest value of $\mathrm{TA} \%$ followed by jasmine oil treatments, then untreated fruits with post-harvest treatments resulted in the lowest value of $\mathrm{TA} \%$ in the $1^{\text {st }}$ season, while wrapping fruits gave the highest value of $\mathrm{TA} \%$, followed by jasmine oil, then the untreated fruit gave the lowest value of $\mathrm{TA} \%$ in the $2^{\text {nd }}$ season.

Regard to the effect of postharvest treatments on $\mathrm{TA} \%$ during the shelf life period under room temperature, it could be demonstrated that the group of fruits sprayed with $\mathrm{CaCl}_{2}$ showed the highest value of TA\% (1.7 \& 1.83\%), followed by the group of fruits sprayed with $\mathrm{GA}_{3}$ $(1.67 \& 1.77 \%)$, then the group of untreated fruits (the control) gave the lowest value of $\mathrm{TA} \% \quad(1.40 \quad \&$ $1.53 \%)$. These effects of spraying both of $\mathrm{GA}_{3}$ or $\mathrm{CaCl}_{2}$ on $\mathrm{TA} \%$ could be due to the causing a delay of ripening and senescence occurring of pomegranate fruits. Furthermore, treated of stored fruits with some natural oils or wrapping fruits with food polyolefin stretch as modified atmosphere packaging (MAP) surrounding the fruits resulted in decreasing $\mathrm{O}_{2}$ levels and increasing $\mathrm{CO}_{2}$ levels inside the MAP compared to the untreated (control) fruits.

These obtained results are in parallel with those reported by Badawy et al. (2016).

\section{3- Effect on TSS/TA ratio in fruit juice:}

As shown in Table (8), it was obviously that pre-harvest spraying with $\mathrm{GA}_{3}(100 \mathrm{ppm})$ and $\mathrm{CaCl}_{2}(4 \%)$, as well as the post-harvest treatments with jasmine oil, olive oil, fiber gard and wrapping fruits resulted in significantly decrease in the TSS/TA ratio in juice of stored fruits under room temperature in 2011 and 2012 seasons.

Concerning the effect of preharvest spraying with $\mathrm{GA}_{3}$ or $\mathrm{CaCl}_{2}$ on TSS/TA ratio in fruit juice of Manfalouty pomegranate cv., it was clear that untreated (control) fruits showed the highest ratio between the $\mathrm{TSS} \%$ and $\mathrm{TA} \%$ in the fruit juice (10.50 \& 10.30), followed by spraying fruits with $\mathrm{GA}_{3}(9.50 \& 8.70)$ and then the fruits sprayed with $\mathrm{CaCl}_{2}$ $(9.20 \& 8.30)$ during seasons 2011 and 2012, respectively. This reduction of TSS/TA ratio in fruit juice could be attributed to decreasing $\mathrm{TSS} \%$ and increasing $\mathrm{TA} \%$ in juice of treated fruits with $\mathrm{GA}_{3}$ and $\mathrm{CaCl}_{2}$ during the 2 studied seasons as aforementioned in the effects of $\mathrm{GA}_{3}$ and $\mathrm{CaCl}_{2}$ on both of $\mathrm{TSS} \%$ and $\mathrm{TA} \%$ in fruit juice.

As well as, the effect of the post-harvest treatments in TSS/TA ratio in fruit juice tock the same trend of the pre-harvest treatment on this parameter. Whereas, the post harvest treatments on the group of untreated (control) fruits gave the highest value of TSS/TA ratio, followed by the group of fruits sprayed with $\mathrm{GA}_{3}$, then the group of fruits sprayed with $\mathrm{CaCl}_{2}$ during the two studied seasons. 
Table 8. Effect of pre- and post-harvest treatments on TSS/TA ratio in juice of "Manfalouty" pomegranate fruits under room temperatures during 2011 and 2012 seasons.

\begin{tabular}{|c|c|c|c|c|c|c|c|c|c|}
\hline \multirow{3}{*}{$\begin{array}{c}\text { Pre-harvest } \\
\text { Treatments } \\
\text { A }\end{array}$} & \multirow{3}{*}{$\begin{array}{c}\text { Post-harvest } \\
\text { Treatments } \\
\text { B }\end{array}$} & \multicolumn{4}{|c|}{2011 season } & \multicolumn{4}{|c|}{2012 season } \\
\hline & & \multicolumn{3}{|c|}{ Periods C } & \multirow[b]{2}{*}{ Mean } & \multicolumn{3}{|c|}{ Periods C } & \multirow[b]{2}{*}{ Mean } \\
\hline & & $\begin{array}{l}\text { Zero } \\
\text { point }\end{array}$ & 1 & 2 & & $\begin{array}{l}\text { Zero } \\
\text { point }\end{array}$ & 1 & 2 & \\
\hline \multirow{6}{*}{ Control } & $\mathbf{O}$ & 11.36 & 12.33 & 14.51 & 12.73 & 11.77 & 13.10 & 15.77 & 13.55 \\
\hline & Jasmine oil & 10.51 & 10.98 & 12.49 & 11.33 & 9.57 & 10.20 & 13.52 & 11.10 \\
\hline & Olive oil & 10.34 & 11.65 & 12.21 & 11.40 & 10.16 & 9.91 & 12.85 & 10.97 \\
\hline & Fiber gard & 9.71 & 11.34 & 12.41 & 11.15 & 11.11 & 11.83 & 13.19 & 12.04 \\
\hline & Wrapping & 10.45 & 11.87 & 13.12 & 11.81 & 8.74 & 9.24 & 12.46 & 10.15 \\
\hline & Mean & 10.50 & 11.60 & 12.90 & 11.67 & 10.30 & 10.90 & 13.60 & 11.60 \\
\hline \multirow{6}{*}{$\begin{array}{c}\mathbf{G A}_{3}(100 \\
\text { ppm) }\end{array}$} & $\mathbf{O}$ & 9.51 & 9.67 & 10.78 & 9.99 & 8.72 & 9.42 & 11.70 & 9.95 \\
\hline & Jasmine oil & 9.87 & 10.14 & 11.49 & 10.50 & 9.66 & 10.02 & 12.07 & 10.58 \\
\hline & Olive oil & 9.59 & 9.63 & 11.31 & 10.18 & 8.03 & 8.36 & 10.73 & 9.04 \\
\hline & Fiber gard & 9.08 & 9.93 & 10.95 & 9.99 & 8.95 & 9.38 & 11.94 & 10.09 \\
\hline & Wrapping & 9.38 & 9.93 & 10.33 & 9.88 & 8.31 & 8.59 & 10.88 & 9.26 \\
\hline & Mean & 9.50 & 9.90 & 11.00 & 10.13 & 8.70 & 9.20 & 11.50 & 9.80 \\
\hline \multirow{6}{*}{$\mathrm{CaCl}_{2}(4 \%)$} & $\mathbf{O}$ & 9.62 & 10.34 & 10.83 & 10.26 & 9.06 & 9.40 & 12.22 & 10.23 \\
\hline & Jasmine oil & 8.72 & 9.22 & 10.63 & 9.52 & 8.48 & 9.02 & 11.60 & 9.70 \\
\hline & Olive oil & 9.14 & 9.94 & 13.58 & 10.89 & 8.32 & 8.17 & 10.28 & 8.92 \\
\hline & Fiber gard & 9.34 & 9.75 & 10.59 & 9.89 & 7.72 & 8.33 & 9.67 & 8.57 \\
\hline & Wrapping & 9.22 & 9.51 & 10.17 & 9.63 & 7.78 & 8.09 & 9.67 & 8.51 \\
\hline & Mean & 9.20 & 9.80 & 11.20 & 10.07 & 8.30 & 8.60 & 10.70 & 9.20 \\
\hline \multicolumn{2}{|c|}{ Mean } & 9.72 & 10.42 & 11.69 & & 9.09 & 9.54 & 11.91 & \\
\hline \multirow{5}{*}{ Mean } & $\mathbf{O}$ & 10.16 & 10.78 & 12.04 & 10.99 & 9.85 & 10.64 & 13.23 & 11.24 \\
\hline & Jasmine oil & 9.70 & 10.11 & 11.54 & 10.45 & 9.24 & 9.75 & 12.40 & 10.46 \\
\hline & Olive oil & 9.69 & 10.41 & 12.37 & 10.82 & 8.84 & 8.81 & 11.29 & 9.65 \\
\hline & Fiber gard & 9.38 & 10.34 & 11.32 & 10.34 & 9.26 & 9.85 & 11.60 & 10.24 \\
\hline & Wrapping & 9.68 & 10.44 & 11.21 & 10.44 & 8.28 & 8.64 & 11.00 & 9.31 \\
\hline & \multirow{2}{*}{\multicolumn{4}{|c|}{0.490}} \\
\hline & \multirow{2}{*}{\multicolumn{4}{|c|}{$\begin{array}{l}0.39 \\
0.51\end{array}$}} & & & & \\
\hline & & \multirow{2}{*}{\multicolumn{4}{|c|}{$\begin{array}{l}0.31 \\
0.39\end{array}$}} & \multicolumn{4}{|c|}{0.632} \\
\hline \multicolumn{2}{|c|}{ C (Period) } & & & & & \multirow{2}{*}{\multicolumn{4}{|c|}{$\begin{array}{l}0.490 \\
1.095\end{array}$}} \\
\hline $\mathbf{A B}$ & $=$ & \multicolumn{4}{|c|}{0.88} & \multicolumn{3}{|c|}{1.095} & \\
\hline AC & $=$ & \multicolumn{4}{|c|}{ n.s } & \multicolumn{4}{|c|}{ n.s } \\
\hline BC & $=$ & \multicolumn{4}{|c|}{ n.s } & & n.s & & \\
\hline $\mathbf{A B C}$ & $=$ & & $\mathrm{n}$. & & & & n.s & & \\
\hline
\end{tabular}

Regard to the effect of postharvest treatments on TSS/TA ratio in fruit juice with each group of sprayed with $\mathrm{GA}_{3}$ or $\mathrm{CaCl}_{2}$ on the untreated (control) fruits, untreated fruits within the control group gave the highest TSS/TA ratio, while jasmine oil treatments gave the highest value of $\mathrm{TSS} / \mathrm{TA}$ ratio in the group of sprayed fruits with $\mathrm{GA}_{3}$, and treated fruits with olive oil in the group fruits treated with $\mathrm{CaCl}_{2}$ gave the highest value of TSS/TA ratio in fruit juice in the $1^{\text {st }}$ season, as well as in the $2^{\text {nd }}$ season, with the exception of untreated fruits in the group of fruits sprayed with $\mathrm{CaCl}_{2}$ gave the highest value of TSS/TA ratio in fruit juice, all results compared with untreated control fruits in 2011 and 2012 season.

The obtained results are in harmony with those pointed out by Tripathi and Bhargave (1993). 


\section{4- Effects on total sugar $\%$ in fruit juice:}

Data indicated in Table (9) that the effects of pre-harvest spraying with $\mathrm{GA}_{3}(100 \mathrm{ppm})$ and $\mathrm{CaCl}_{2}(4 \%)$, and post-harvest treatments with jasmine oil, olive oil, fiber gard and wrapping fruits revealed significantly decrease in the total sugars $\%$ in fruit juice of Manfalouty pomegranate cv. in the $1^{\text {st }}$ season 2011, while induced significantly increase in the total sugars $\%$ in fruit juice in the $2^{\text {nd }}$ season 2012 .

Concerning the effect of preharvest spraying with $\mathrm{GA}_{3}$ or $\mathrm{CaCl}_{2}$ on the total sugars $\%$ in fruit juice, at could deduced that untreated fruits (control) gave the highest value of the total sugars \% (11.4\%) followed by pre-harvest spraying with $\mathrm{GA}_{3}$ $(11.10 \%)$, then spraying $\mathrm{CaCl}_{2}$ gave the lowest value of the total sugars \% in the $1^{\text {st }}$ season, while in the $2^{\text {nd }}$ season, spraying $\mathrm{CaCl}_{2}$ gave the highest value of the total sugars $\%(12.10 \%)$, followed by spraying $\mathrm{GA}_{3}(11.50 \%)$, then the untreated (control) fruits gave the lowest value of total sugars $(11 \%)$ in fruit juice.

Regard to the effect of postharvest treatments in total sugars \%, in juice of stored fruits under room temperature, the results showed the same trend of the pre-harvest treat- ments on this parameter during the 2 studied seasons compared with untreated (control) fruits.

Within each group of fruits treated or untreated with the postharvest treatments, it was obviously that within the untreated (control) fruits. Fiber gard treatments gave the highest value of total sugars $\%$, while wrapping fruits gave the lowest total sugars $\%$ in fruit juice at the $1^{\text {st }}$ season. On the other hand, untreated fruit with post-harvest treatments gave the highest value of total sugars $\%$, and jasmine oil treatment gave the lowest value of total sugars $\%$ in the $2^{\text {nd }}$ season.

Within the group of fruits sprayed with $\mathrm{GA}_{3}$, untreated fruits gave the highest value of total sugars $\%$, and treatment with fiber gard gave the lowest value of total sugars $\%$ in the $1^{\text {st }}$ season, as well as, in the $2^{\text {nd }}$ season untreated fruits gave the highest value of total sugars $\%$, while wrapping fruits results in the lowest value of total sugars $\%$. Within the group of fruits sprayed with $\mathrm{CaCl}_{2}$ during the two studied season untreated fruits induced the highest value of total sugars $\%$ and wrapping fruit gave the lowest value of total sugars $\%$, compared with untreated fruits. 
Table 9. Effect of pre- and post-harvest treatments on total sugars \% of "Manfalouty" pomegranate cv. under room temperatures during 2011 and 2012 seasons.

\begin{tabular}{|c|c|c|c|c|c|c|c|c|c|}
\hline \multirow{3}{*}{$\begin{array}{c}\text { Pre-harvest } \\
\text { Treatments } \\
\text { A }\end{array}$} & \multirow{3}{*}{$\begin{array}{c}\text { Post-harvest } \\
\text { Treatments } \\
\text { B }\end{array}$} & \multicolumn{4}{|c|}{2011 season } & \multicolumn{4}{|c|}{2012 season } \\
\hline & & \multicolumn{3}{|c|}{ Periods C } & \multirow[b]{2}{*}{ Mean } & \multicolumn{3}{|c|}{ Periods C } & \multirow[b]{2}{*}{ Mean } \\
\hline & & $\begin{array}{l}\text { Zero } \\
\text { point }\end{array}$ & 1 & 2 & & $\begin{array}{l}\text { Zero } \\
\text { point }\end{array}$ & 1 & 2 & \\
\hline \multirow{6}{*}{ Control } & $\mathbf{O}$ & 11.67 & 12.27 & 12.65 & 12.20 & 11.38 & 12.26 & 12.48 & 12.04 \\
\hline & Jasmine oil & 11.47 & 12.32 & 12.78 & 12.19 & 11.03 & 12.07 & 12.57 & 11.89 \\
\hline & Olive oil & 11.07 & 12.48 & 12.77 & 12.11 & 10.97 & 12.28 & 12.62 & 11.96 \\
\hline & Fiber gard & 11.43 & 12.50 & 12.77 & 12.23 & 11.38 & 12.07 & 12.53 & 11.99 \\
\hline & Wrapping & 11.23 & 12.10 & 12.60 & 11.98 & 11.37 & 11.98 & 12.40 & 11.92 \\
\hline & Mean & 11.40 & 12.30 & 12.70 & 12.13 & 11.20 & 12.10 & 12.50 & 11.93 \\
\hline \multirow{6}{*}{$\begin{array}{c}\mathbf{G A}_{3}(100 \\
\text { ppm) }\end{array}$} & $\mathbf{O}$ & 11.53 & 12.23 & 12.87 & 12.21 & 11.93 & 12.74 & 12.91 & 12.53 \\
\hline & Jasmine oil & 11.47 & 12.40 & 12.67 & 12.18 & 11.57 & 12.71 & 12.85 & 12.38 \\
\hline & Olive oil & 10.97 & 11.95 & 12.62 & 11.85 & 11.17 & 12.30 & 12.58 & 12.02 \\
\hline & Fiber gard & 10.83 & 11.53 & 12.27 & 11.54 & 11.52 & 11.97 & 12.72 & 12.07 \\
\hline & Wrapping & 10.77 & 11.8 & 12.47 & 11.68 & 11.30 & 12.18 & 12.52 & 12.00 \\
\hline & Mean & 11.10 & 12.00 & 12.60 & 11.90 & 11.50 & 12.40 & 12.70 & 12.20 \\
\hline \multirow{6}{*}{$\mathrm{CaCl}_{2}(4 \%)$} & $\mathbf{O}$ & 11.33 & 12.20 & 12.82 & 12.12 & 12.12 & 12.90 & 13.27 & 12.76 \\
\hline & Jasmine oil & 11.17 & 12.00 & 12.70 & 11.96 & 12.22 & 12.65 & 13.35 & 12.74 \\
\hline & Olive oil & 10.90 & 12.12 & 12.53 & 11.85 & 12.07 & 12.81 & 13.18 & 12.69 \\
\hline & Fiber gard & 10.70 & 11.85 & 11.97 & 11.51 & 12.13 & 12.55 & 12.93 & 12.54 \\
\hline & Wrapping & 10.53 & 11.53 & 11.75 & 11.27 & 11.80 & 12.33 & 12.93 & 12.35 \\
\hline & Mean & 10.90 & 11.9 & 12.40 & 11.73 & 12.10 & 12.60 & 13.10 & 12.60 \\
\hline \multicolumn{2}{|c|}{ Mean } & 11.14 & 12.08 & 12.55 & & 11.60 & 12.38 & 12.79 & \\
\hline \multirow{5}{*}{ Mean } & $\mathbf{O}$ & 11.51 & 12.23 & 12.78 & 12.17 & 11.81 & 12.63 & 12.89 & 12.44 \\
\hline & Jasmine oil & 11.37 & 12.24 & 12.72 & 12.11 & 11.61 & 12.48 & 12.92 & 12.34 \\
\hline & Olive oil & 10.98 & 12.18 & 12.64 & 11.93 & 11.40 & 12.46 & 12.79 & 12.22 \\
\hline & Fiber gard & 10.99 & 11.96 & 12.34 & 11.76 & 11.68 & 12.20 & 12.73 & 12.20 \\
\hline & Wrapping & 10.84 & 11.81 & 12.27 & 11.64 & 11.49 & 12.16 & 12.62 & 12.09 \\
\hline \multicolumn{6}{|l|}{ L.S.D. 0.05} & \multirow{2}{*}{\multicolumn{4}{|c|}{0.115}} \\
\hline \multirow{2}{*}{\multicolumn{2}{|c|}{$\begin{array}{l}\text { A (Pre) } \\
\text { B (Post) }\end{array}$}} & \multirow{2}{*}{\multicolumn{4}{|c|}{$\begin{array}{l}0.0 \\
0.1\end{array}$}} & & & & \\
\hline & & & & & & \multicolumn{4}{|c|}{0.149} \\
\hline \multicolumn{2}{|c|}{ C (Period) } & \multicolumn{4}{|c|}{0.08} & \multicolumn{4}{|c|}{0.115} \\
\hline AB & $=$ & \multicolumn{4}{|c|}{0.17} & \multicolumn{4}{|c|}{0.257} \\
\hline AC & $=$ & \multicolumn{4}{|c|}{ n.s } & \multirow{2}{*}{\multicolumn{4}{|c|}{ n.s }} \\
\hline BC & $=$ & \multicolumn{4}{|c|}{0.17} & & & & \\
\hline $\mathbf{A B C}$ & $=$ & & $\mathrm{n}$. & & & & n.s & & \\
\hline
\end{tabular}

In general, the combination of pre- and post-harvest treatments effect on total sugars $\%$ in juice of stored fruits under room temperature, untreated fruits resulted in the highest value of total sugars \% and wrapping fruits induced the lowest value of total sugars $\%$. These positive effects of pre- and post-harvest treatment on stored fruits under room temperature could be due to reducing the respiration rate as well as the senescence of fruits stored under room temperature by decreasing $\mathrm{O}_{2}$ and increasing $\mathrm{CO}_{2}$ under modified atmosphere packag- ing of fruits stored under room temperature as pointed out by White and Broadley, 2003; Lara et al., 2004; Caleb et al., 2012 and Selcuk and Erkan, 2014, 2015).

These obtained results are in accordance with those found by Nurten and Mustafa (2013).

\section{References}

A.O.A.C. (2000). Association of Official Agricultural Chemists. Official Methods of Analysis (A.O.A.C) $15^{\text {th }}$ ed, Published by A.O.A.C. Washington, D.C, U.S.A. pp: 490510. 
Arendse, E.; Fawole, O.A. and Opara, U.L. (2014). Effect of post harvest storage conditions on phytochemical and radical scavenging activity of pomegranate fruits (cv. Wonderfull). Sci. Hortic., 169:125-129.

Arhtas, A.; Abbasi, N.A. and Hussain, A. (2010). Effect of calcium chloride treatments on quality characteristics of "Laquate" fruit during sotrage. Pakistan J. of Bot. 42: 181-188.

Aries, F.; Tudela, J.A. and Villaescuse, R. (2000). Thermal post-harvest treatments for improving pomegranate quality and shelf like. Post harvest Biol. Tedmol., 18: 245-251.

Badawy, I.F.M.; R.A. Ibrahim and F.M. Gouda (2016). Effect of some post-harvest treatments on storability and quality of Manfalouty pomegranate fruits at Ambient temperature. Assiut J. Agric. Sci., 47 (3): 78-91.

Caleb, O.J.; Opara, U.L. and Withulm, C.R. (2012). Modified atmosphere packaging of pomegranate fruit and arils, a review. Food Bioprocess Technol., 5: 15-30.

Fawole, O.A. and Opara, U.L. (2013a). Effects of storage and duration on physiological responses of pomegranate fruits. Ind. Crops and Prod., 47: 300-309.

Fawole, O.A. and Opara, U.L. (2013b). Effect of maturity status on biochemical concentration, polyphenol composition and antioxidant capacity of pomegranate fruit arils (cv. Bhagwa). S. Afr. J. Bot., 85: 23-31.

Gomez, K.A. and Gomez, A.A. (1984). Statistical Procedures for Agricultural Researches (the $2^{\text {nd }}$ ed.) Published by John Wiley and Sons, New York, U.S.A. pp: 10HigazZ,0A.M.; M.H. El-Hagah; S.Z. ElNaggar and A.A. Kassem (1983).
Physical, chemical characters of Le-Conte pear fruit in relation to gibberellic acid effects. Minufiya Journal of Agricultural Research, 281-299.

Jumaa, F.F. and A.A. Ali (2016). Effect of foliar application of potassium zinc and gibberellic acid on yield and some fruit quality of pomegranate cv. Salimy. The Iraqi Journal of Agricultural Sciences, 42 (2): 524-532.

Jumaa, F.F. and A.A. Ali (2016). Effect of foliar application of potassium zinc and gibberellic acid on yield and some fruit quality of pomegranate cv. Salimy. The Iraqi Journal of Agricultural Sciences, 42 (2): 524-532.

Khalil, H.A. and Aly, H.S. (2013). Cracking and fruit quality of pomegranate as affected by preharvest sprays of some growth regulators and mineral nutrients. $\mathrm{J}$. Hort. Sci. Ornam. Plant, 5: 71-76.

Korkmaz, N., Askin, M.A., Ercisli, S., \& Okatan, V. (2016). Foliar application of calcium nitrate, boric acid and gibberellic acid affects yield and quality of pomegranate (Punica granatum L.). Acta Scientiarum PolonorumHortorum Cultus, 15(3), 105-112.

Lara, J.; Garca, P. and Vendrell, M. (2004). Modification of cell wall compositon after cold storage of calcium treated strawberry fruit. Post harvest Biol. Technol., 34: 331-339.

Mahajan, B.V. and Dhatt, A.S. (2004). Studies on post-harvest calcium chloride applciation on storage behaviour and quality of Asian pear during cold storage. J. Food Agric. \& Enviroin., 2: 157-159.

Mena, P.; Garcia, V.C.; Navana, R.J.; Mareno, D.A.; Bartual, J.; Saura, D. and Marti, N. (2011). Phytochemical characterization for in- 
dustrial use of pomegranate cvs. grown in Spain. J. Sci. Food Agric., 91: 1893-1906.

Mir, N.A.; J.N. Bhat and A.R. Bhat (1993). Effect of calcium infiltration on storage behaviour of "Red Delicious" apples. Indian Journal of Plant Physiology, 36 (1): 65-66. Hort. Abst. 64 (2), 908.

Mphahlele, R.R.; Fawole, O.A. and Opara, U.L. (2016). Influence of packaging system and long term storage on physiological attributes, biochemical quality, volatile composition and antioxidant properties of pomegranate fruit. Sci. Horti., 211: 140-151.

Nanda, S.; Sudhakar, R.D. and Kirshnamurthy, S.(2001). Effects of shrink film wrapping and storage temperature on the shelf life and quality of pomegranate fruits $\mathrm{cv}$. Ganesh. Post-harvest. Biol. Technol., 22: 61-69.

Nurten, S. and E. Mustafa (2013). Impact of passive modified atmosphere packaging on physicchemical properties, bioactive compounds, and quality attributes of sweet pomegranates. Turk Journal Agric. 40: 475-488.

Opara, U.L.; Al-Ani, M.R. and AlShaubi, Y.S. (2009). Physicochemical properties, vitamin $\mathrm{C}$ content and antimicrobial properties of pomegranate fruit (Punica granatum L.). Food Technology, 2: 315-321.

Samar, A.M.A.; Shaara, W.I.; Assem, S.E.; Salem Ibrahim M.K. ElMaghraby, Eman A.A. AbdelMoniem (2016). Effect of salicylic acid calcium chloride and calcium lactate. Applications on Quality attributes of minimally-processed "Wonderful" pomegranate Arils, Not Bot Horti. Agrobo, 44 (2): 508-517.
Selcuk, N. and Erkan, M. (2014). Change in antioxidant activity and post harvest quality of sweet pomegranate cv. Hicrannar under modified atmosphere packaging. Post harvest Biol. Technol. 92: 2936.

Selcuk, N. and Erkan, M. (2015). Changes in phenolic compounds and antioxidant activity of soursweet pomegranate cv. Hicaznar during long term storage under modified atmosphere packaging. Post harvest Biol. Technol., 109: 30-39.

Selcuk, N. and Erkan, M. (2016). Impact of passive modified atmosphere packaging on physiochemical properties bioactive compounds and quality attributes of sweet pomegranates. Turk. J. Agric. Forestry, 40: 475-488.

Singh, D.B.; Sharma, B.D. and Dhargava, R. (2003). Effect of Boron and $\mathrm{GA}_{3}$ to control fruit cracking in pomegranate. Cut. Agric. 27: 125-127.

Snedecor, G.W. and Cochran, W.G. (1980). Statistical Methods. Iowa State University, Ames, USA.

Tripathi, S.N. and J.N. Bhargave (1993). Effect of pre-harvest treatments of fungicides and chemicals on the post-harvest behaviour of "Red Delicious" apple in air-cooled storage. Advances in Horticulture and Forestry, 3: 77-79. Hort. Abst. 65 (9), 7717.

Vinda-Martos, M.; Fernandez, L.J. and Perog, A. (2010). Pomegranate and its many functional components as related to human health, A review. Comprehensive Reviews in Food Science and Food Safety, 9: 635665.

White, P.J. and Broadley, M.R. (2003). Calcium in plants. Annal. Of Bot., 92: 487-511. 
تأثثير معاملات ما قبل وبعد الحصاد علي جودة وقابلية ثمار الرمان المنفلوطي للتخزين تحت درجة حرارة الغرفة وابلة

فاروق محمد أحمد مصطفي'، علاء عبد الجابر بدوي '، رشاد عبد الوهاب ابراهيم' ، فاطمة عصمت

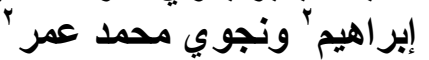

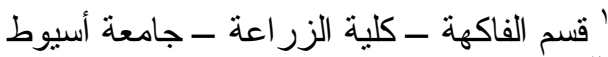

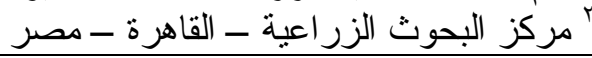

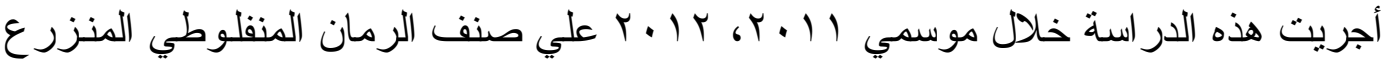

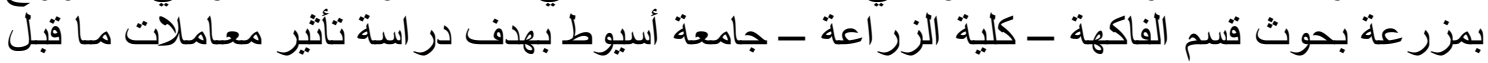

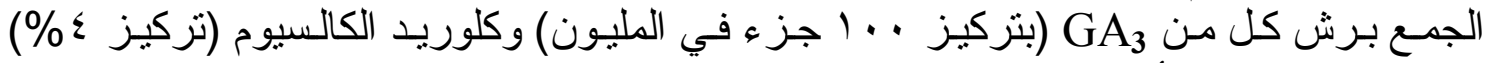

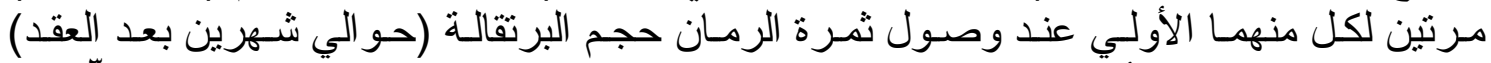

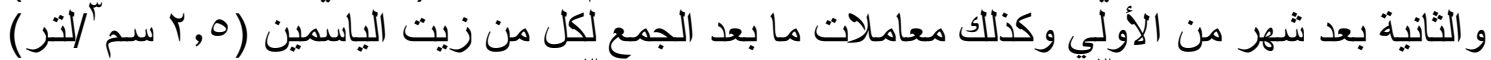

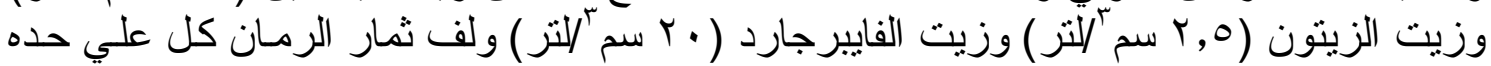

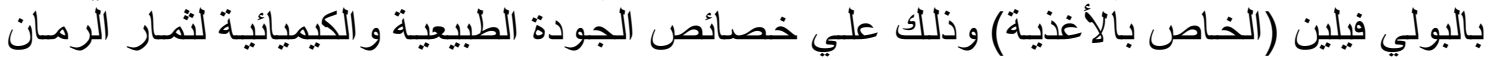

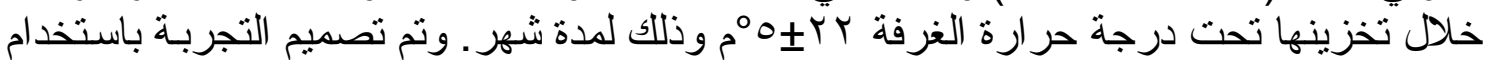

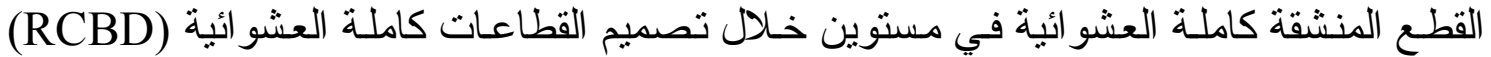

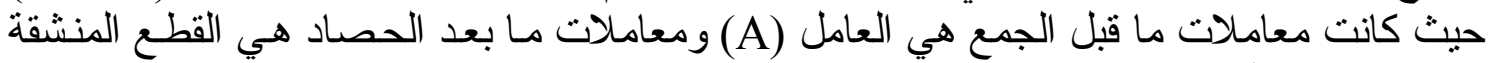



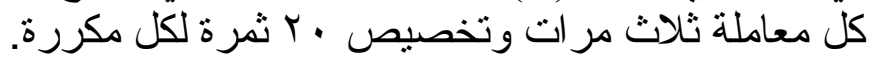

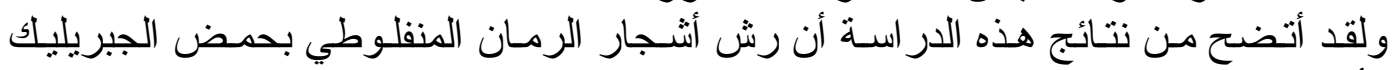

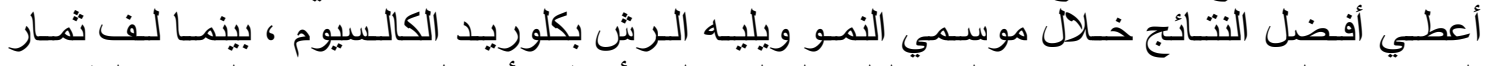

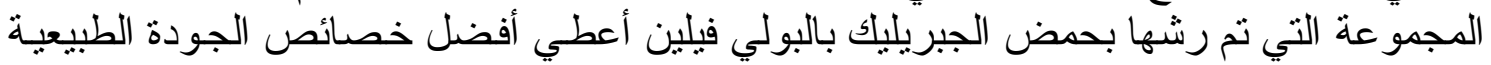

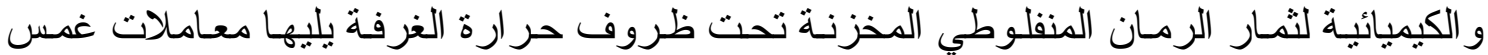

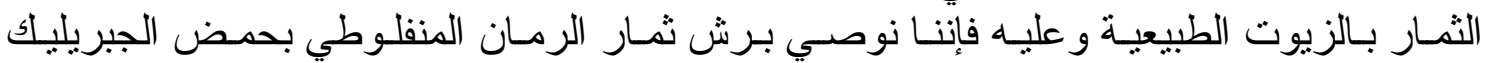

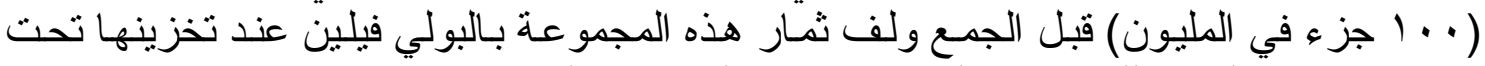
ظروف حر ارة الغرفة للمحافظة علي خصل فيائصها الطبيعية و الكيميائية. 